University of Michigan Law School University of Michigan Law School Scholarship Repository

Articles

Faculty Scholarship

2014

\title{
Understanding the AMT, and its Unadopted Sibling, the AMxT
}

James R. Hines Jr.

University of Michigan Law School, jrhines@umich.edu

Kyle D. Logue

University of Michigan Law School, klogue@umich.edu

Available at: https://repository.law.umich.edu/articles/1564

Follow this and additional works at: https://repository.law.umich.edu/articles

Part of the Legislation Commons, Taxation-Federal Commons, and the Tax Law Commons

\section{Recommended Citation}

Hines, James R., Jr. "Understanding the AMT, and its Unadopted Sibling, the AMxT." K. D. Logue, co-author. J. Legal Analysis 6, no. 2 (2014): 367-408.

This Article is brought to you for free and open access by the Faculty Scholarship at University of Michigan Law School Scholarship Repository. It has been accepted for inclusion in Articles by an authorized administrator of University of Michigan Law School Scholarship Repository. For more information, please contact mlaw.repository@umich.edu. 


\title{
UNDERSTANDING THE AMT, AND ITS UNADOPTED SIBLING, THE AMxT
}

James R. Hines Jr* and Kyle D. Logue**

\begin{abstract}
Four million Americans with extensive tax preferences are subject to the Alternative Minimum Tax (AMT). By taxing a broad definition of income, the AMT makes it possible to have a tax system that both encourages certain activities with generous tax preferences and maintains a semblance of distributional equity. The same rationale supports the imposition of an Alternative Maximum Tax (AMxT), which would cap tax liabilities of individuals with very few preference items and thereby afford Congress greater flexibility in designing the income tax. The original 1969 AMT proposal included an AMxT; it is difficult to justify imposing one without the other.
\end{abstract}

\section{INTRODUCTION}

The Alternative Minimum Tax (AMT) is a parallel federal tax regime that operates alongside the regular U.S. income tax (I.R.C. \$\$ 55-59 (2013); U.S. Congress Joint Economic Committee 2001). ${ }^{1}$ Taxpayers compute their federal tax liabilities twice, once under the regular income tax and a second time under the AMT; whichever tax liability is higher is the total amount that the taxpayer owes the government (I.R.C. $\$ 55$ (2013); U.S. Congress Joint Economic

* University of Michigan Law School, E-mail: jrhines@umich.edu. The authors thank David Albouy, Joe Bankman, Jennifer Bird-Pollan, Adam Cole, Brian Galle, Tim Goodspeed, Dan Halperin, David Hasen, Doug Kahn, Louis Kaplow, Daniel Kessler, Wojciech Kopczuk, Alex Roskalnikov, David Schizer, Steve Shay, Joel Slemrod, James Wetzler, and seminar participants at the University of Michigan, Stanford Law School, the University of Kentucky, Columbia Law School and Harvard Law School for many helpful comments on earlier drafts of this article. Mark Ramseyer and two anonymous referees provided several helpful suggestions that are incorporated in this draft.

** University of Michigan Law School

1 Corporations as well as individuals are subject to an AMT, but this article concerns only the individual AMT.

(C) The Author 2014. Published by Oxford University Press on behalf of The John M. Olin Center for Law, Economics and Business at Harvard Law School.

This is an Open Access article distributed under the terms of the Creative Commons Attribution Non-Commercial License (http://creativecommons.org/licenses/by-nc/4.0/), which permits non-commercial re-use, distribution, and reproduction in any medium, provided the original work is properly cited. For commercial re-use, please contact journals.permissions@oup.com 
Committee 2001, pp. 2-4.). ${ }^{2}$ The regular income tax has a progressive marginal tax rate structure and a base that is affected by numerous deductions, credits, and preferential tax rates for specific activities and income sources. By comparison, the AMT has a larger exemption level and much less progressive marginal tax rates, together with a considerably broader tax base that removes many of the preferences contained in the regular income tax. Taxpayers are likely to be subject to the AMT if they have high incomes and are eligible for many tax preferences under the regular income tax that are disallowed under the AMT. ${ }^{3}$

Why does the USA have an AMT? From the standpoint of public opinion, the AMT may be the most widely condemned part of a generally unpopular tax regime. ${ }^{4}$ The AMT is commonly criticized for introducing inefficient incentives, arbitrary tax burdens, and outrageous complexity (Gale 2006; President's

2 In tax argot, taxpayers always pay the regular tax; AMT liability, when applicable, is the extra portion attributable to the AMT - the difference between total tax liability under the AMT rules and liability under the regular income tax. See I.R.C. $\$ 55$ (a) (2012) ("There is hereby imposed (in addition to any other tax imposed by this subtitle) a tax equal to the excess (if any) of . . . the tentative minimum tax for the taxable year, over... the regular tax for the taxable year.") For convenience, this article refers to alternative tax liability as a taxpayer's entire obligation, not merely the difference between the alternative tax liability and liability under the regular income tax.

3 See, e.g., O'Shaughnessy (2006, p. 68) (“The goal of policy-makers who enacted the AMT was to prevent those taxpayers with substantial economic income from lawfully avoiding any tax liability through exclusions, deductions or credits.”).

4 See Aitsebaomo (2005, p. 350) (stating that one justification for the repeal of the AMT is that it disproportionately impacts middle class individual taxpayers with large families by disallowing the personal and dependency exemptions ordinarily allowed as deductions in computing regular federal income tax liability - a result not intended by Congress in drafting the AMT); Beale (2004, p. 842) (noting that by lowering regular tax rates in the 2001 and 2003 tax cuts while leaving the AMT rates the same, Congress expanded the reach of the AMT, requiring more taxpayers to pay additional tax compared to their regular tax computations); Burman, Gale \& Rohaly (2003b, p. 181) (arguing that the AMT's complexity makes understanding tax rules much more difficult); Griffin, (2004, p. 260) (noting that while Congress designed the AMT to focus on the rich, it is the middle class that will bear the main burden of the AMT); Hennig, Gelman \& Everett (2008, p. 38) (noting common taxpayer complaints regarding the AMT: taxpayers should not be expected to anticipate tax penalties that may increase their AMT exposure, the AMT no longer fulfills Congress's goal of targeting the rich, taxpayers should not be subject to the AMT as a result of electing to not take a deduction, etc.); O'Shaughnessy (2006, pp. 74-75) (emphasizing that the AMT's disallowance of deducting state and local taxes bears negative consequences for states as well as individual taxpayers, as the latter will be more resistant to a state's attempt to raise state taxes); Peroni (2003, p. 398) (arguing that the 90 percent limit on the foreign tax credit in $\$ 59(\mathrm{a})(2)$ is arbitrary and capricious, contravening the policy underlying foreign tax credit provisions by double taxing a taxpayer's foreign source income); Sager \& Cohen (2000, pp. 1089-93) (criticizing the ATM for disallowing a deduction for attorney's fees in litigation and thereby discouraging the pursuit of civil rights claims); Burman, Gale \& Rohaly (2003a, p. 115) (noting that the IRS and National Taxpayer Advocate have denoted the AMT as one of the most complicated tax provisions to administer); Burman \& Leiserson (2007, p. 945) (suggesting repealing the AMT and replacing it with an add-on tax of four percent of adjusted gross income for individuals making $\$ 100,000$ and couples making $\$ 200,000$, periodically adjusted for inflation). 
Advisory Panel on Federal Tax Reform 2005). ${ }^{5}$ Moreover, as the fraction of taxpayers subject to the AMT has grown over time, due largely to the absence of indexing (and in part to reduced rates under the regular tax), the frequency and urgency of the calls for AMT reform, and for outright repeal, have grown as well. ${ }^{6}$ Yet the AMT persists for middle- and higher-income taxpayers, maintained by the budgetary cost of repeal ${ }^{7}$ and possibly the grudging acknowledgement that the AMT performs a function of which voters and lawmakers at least tacitly approve. ${ }^{8}$ Indeed, in 2013 Congress reaffirmed its apparent long-term commitment to the AMT when it made a new round of important changes to the regime, including a new exemption amount that is, for the first time, permanently indexed for inflation (American Taxpayer Relief Act of 2012).

This Article considers an important function of the AMT that has its roots in the justification articulated by the U.S. Treasury when it first proposed the AMT in 1969. The AMT makes it possible for Congress to adopt a regular income tax that has two attributes that have long been fundamental aspects of the U.S. tax system: progressive tax burdens ${ }^{9}$ and preferential tax treatment of certain activities. ${ }^{10}$ If Congress wants to structure a regular income tax that has both of those

5 See President's Advisory Panel on Federal Tax Reform (2005) (referring to the AMT as "a complex, unfair, and inefficient burden on millions of Americans ... ."); Burman et al., (2007, p. 404) (“[T]he AMT will come to plague the middle — and upper-middle—income classes with undue complexity, a narrower tax base, and higher marginal rates than under the regular income tax.").

6 See Harvey \& Tempalsky (1997, p. 453) ("The reason for the projected sharp increase in the number of AMT taxpayers is that the main parameters (i.e., personal exemption, standard deduction, and tax-bracket widths) of the regular tax are indexed for inflation, whereas the main parameters of the AMT are not. Each year, inflation puts more taxpayers onto the AMT.")

7 See Feenberg \& Poterba (2004, p. 409) ("Although it is widely criticized, the AMT may prove difficult to eliminate in the current fiscal environment. The AMT is projected to become a substantial source of federal tax revenue between 2006 and 2010 period. Eliminating the AMT would, therefore, raise the federal budget deficit, place pressure on expenditure programs, or require increases in other taxes;") see also Congressional Budget Office (2010, p. 9) (stating that eliminating the AMT altogether would impose a revenue cost of over $\$ 620$ billion from 2010 to 2019).

8 See U.S. Congress Joint Economic Committee (2001, p. 1) ("The goal of the AMT for individuals is to make everyone with significant income pay some federal income tax"); Beale (2004, p. 813) (noting that the AMT's purpose was to ensure that taxpayers could not overuse various tax provisions to slip out of paying any tax altogether).

9 See U.S. Congress Joint Committee on Taxation (2004) ("One of the basic tenets of tax policy is that an accurate measurement of ability to pay taxes is essential to tax fairness"); and Lindsey (2001, p. 3) ("Our present scheme of taxation is intended to promote vertical equity, which means that the higher income taxpayer should pay a higher level of taxes based on an ability-to-pay concept.").

10 See Surrey (1970, p. 705) (stating that Congress's purpose in allowing tax incentives is to assist certain industries and business activities, and to encourage non-business activities considered socially useful, such as contributions to charity). 
attributes, which appears to be the case, ${ }^{11}$ and, critically, if one makes the plausible assumption that individual taxpayers are heterogeneous with respect to their taste for, or ability to take advantage of, tax preference provisions, then there is a distributional equity argument to be made for some form of AMT to back up the regular tax system. ${ }^{12}$ While supporters of the AMT have noted this point in its defense (Graetz \& Sunley 1988), this argument carries implications both for the AMT and for broader aspects of tax design that warrant significant additional exploration.

There is an inherent tension between progressivity and the use of tax preferences. In the absence of an AMT, there are likely to be disparities in effective tax rates between those taxpayers who have a strong taste (or comparative advantage) for tax preferences ("tax-preference preferers") and those who do not ("nonpreferers"). Such disparities can undermine the distribution of tax burdens that a progressive tax system seeks to achieve, since a progressive tax is designed to impose higher average tax rates on taxpayers with greater incomes, and by implication equal average tax rates on taxpayers with equal incomes. ${ }^{13}$ Although society is prepared to tolerate some sacrifice of progressivity in the interest of encouraging particular activities and expenditures-as evidenced by the existence of taxpreference provisions in the first place ${ }^{14}$ - there is a limit to the amount of progressivity society is willing to give up for that purpose. The AMT, in an admittedly rough and less than ideal way, places a lower limit on the

11 See Bittker (1972, p. 54) ("What Congress has enacted is a progressive structure with deductions; you cannot hold up one as the authentic voice of the people, and condemn the other as a craven surrender to special privilege.”)

12 Even if taxpayers differed only in their abilities to earn income, and not in their preferences for tax-favored activities, then there might nonetheless be a rationale for AMT-like features in the income tax if there are diminishing social benefits of otherwise tax-favored activities by taxpayers at certain contribution and income levels. For example, if marginal charitable contributions by high-income taxpayers who tend to contribute large fractions of their incomes have fewer social benefits than do contributions by other taxpayers, then there is an efficiency justification for reducing the tax benefits of charitable contributions by the first group of taxpayers. This possibility is not the focus of our argument because its implications turn critically on the (unknown) extent to which the social benefits of otherwise tax-favored activities vary across different income groups in the population.

13 See Musgrave \& Thin (1948) (describing tax burdens under progressive taxation); and Elkins (2006, p. 43) ("The principle of horizontal equity demands that similarly situated individuals face similar tax burdens.”).

14 See Surrey (1970) (“The tax code contains a great number of special provisions which provide credits, deductions, and other tax advantages intended to achieve non-tax goals considered desirable by Congress.”). 
amount of progressivity that can be sacrificed by the heavy use of tax preferences by tax-preference preferers. ${ }^{15}$

But what about the other end of the spectrum, taxpayers who use very few tax preferences? If there is an inherent tension between society's goal of pursuing progressivity and its goal of influencing behavior through the use of tax preferences, that tension will be manifested at both ends of the spectrum. Therefore, just as the heavy use of tax preferences by tax-preference preferers can defeat efforts to achieve an appropriate degree of tax progressivity, so can the light (or non-) use of tax preferences by tax-preference nonpreferers. ${ }^{16}$ As a result, if the country seeks to maintain a certain degree of progressivity, which entails limiting differences in tax burdens between the heaviest and lightest users of tax preferences, and the country is also committed to making significant use of tax preferences, then, in addition to an Alternative Minimum Tax there is a role for an Alternative Maximum Tax, an AMxT. An AMxT limits a taxpayer's ultimate liability to the lower of the amount due under the regular income tax and the amount due under an alternative regime with a broader tax base but a maximum rate below that in the regular income tax. The function of an AMxT, which would use the same tax base as the AMT, would be to impose an upper limit on progressivity. As a result, the introduction of an AMxT allows Congress to adopt higher top marginal tax rates for the highest earning individuals while still making substantial use of tax preferences, without having to worry that the tax-preference nonpreferers would be overtaxed. The AMT and AMxT thereby work together to make possible a judicial balance between progressivity and tax-preference use.

An important caveat is that tax preferences do not necessarily benefit taxpayers who use them, as market competition can reduce pretax returns to tax-favored activities. A familiar example is tax-exempt debt, which carries an implicit tax in the form of reduced yields, as a result of which much of the tax saving benefits bond issuers rather than investors. ${ }^{17}$ The extent to which taxpayers benefit from tax preferences is generally a function of supply and demand conditions in the relevant markets. Equity considerations therefore

15 See U.S. Congress Joint Economic Committee (2001, p. 1) (stating that the AMT-originally designed to reduce certain deductions frequently claimed by high-income taxpayers and infrequently by other taxpayers - has fewer tax preferences than the regular tax).

16 Cf. Bittker (1972, p. 47) (stating that taxpayers in the same position utilizing deductions in differing amounts frustrates horizontal equity).

17 Investors in tax-exempt bonds pay significant implicit taxes in the form of reduced yields even though they may have little or no explicit federal tax liability; for a discussion see Poterba (1986). More generally, federal tax policy affects many market prices, imposing implicit burdens that may differ substantially from legal obligations, as discussed by Fullerton and Metcalf (2002). 
suggest adjustments only to the extent that taxpayers actually benefit from preference items, which varies between preferences items and changes over time.

A different description of the combination of an AMT and AMxT is that it offers insurance for taxpayers and tax policymakers. The tax system contains many complex provisions that interact to produce taxpayer burdens with possibly arbitrary features. ${ }^{18}$ An AMT prevents tax burdens-measured as individual tax obligations-from falling below a specified level, given a particular definition of income (I.R.C. $\$ 55(\mathrm{a})-(\mathrm{b})(1)(\mathrm{A})$ (2012) (as modified by Rev. Proc. 2013-15, 2013-5 I.R.B. 444 (2013)). Correspondingly, an AMxT prevents the tax burdens of individual taxpayers from rising above a specified level. From the standpoint of a taxpayer who would otherwise pay the regular income tax, the AMxT offers insurance against facing too high a tax rate, and this insurance comes at the cost of possibly being subject to the AMT and therefore not benefiting from too low a tax rate.

An AMT/AMxT combination also offers a type of insurance for Congress itself, or for society, whom Congress represents. Start with the assumption that Congress sometimes wants to use provisions in the tax laws to alter taxpayer incentives, perhaps to encourage taxpayers to engage in activities that produce beneficial externalities. ${ }^{19}$ A problem with this strategy, however, is that some taxpayers may use the tax incentives to an extent that threatens to undermine progressivity norms by reducing tax liabilities too much relative to economic incomes. ${ }^{20}$ Having an AMT and AMxT in place addresses this risk by placing limits on the cumulative progressivity effect that the combination of tax incentive provisions can have for any particular taxpayer.

Thus, the fundamental purpose of enacting an AMxT is to afford Congress the latitude to impose a progressive tax rate structure, with possibly rather high top marginal rates, without having to worry excessively about the consequences for high-income taxpayers who have few tax preference items. Any choice of statutory tax rate schedule is made against the background of anticipated tax payments by affected taxpayers, but the challenge is that taxpayers can be

18 See, e.g., Gensler (1985, p. 279) (describing the complexity of the Internal Revenue Code).

19 See Surrey (1970, p. 705) (describing Congress's use of tax advantages as a means to incentivize certain taxpayer activities).

20 See id., 720-25 (illustrating the threat that tax incentives pose to progressivity and the notion that such incentives often fail to serve their true intended purpose); cf. id., 719 ("It is generally argued that tax incentives are wasteful because some of the tax benefits go to taxpayers for activities which they would have performed without the benefits. When this happens, the tax credit or other benefit is a pleasant windfall, and stimulates no additional activity ... [I]t is often difficult to structure a tax credit system which avoids this problem without increasing complexity and introducing arbitrariness.”). 
extremely heterogeneous. ${ }^{21}$ Aware that many well-advised high-income taxpayers have significant tax preference items that reduce their taxable incomes, Congress may be tempted to impose high tax rates on this group in order to achieve the desired distribution of tax burdens. ${ }^{22}$ Congressional zeal to impose high marginal tax rates may be tempered, however, by the awareness of possible tax consequences for taxpayers without many preference items, who could be excessively burdened by very high tax rates. The function of an AMxT is to allay at least some of these Congressional concerns, and thereby afford greater flexibility in setting regular income tax rates. This is analogous to the role of the AMT in giving Congress greater flexibility to offer tax preferences without worrying excessively over the possibility that large numbers of high-income taxpayers would thereby be able to avoid significant tax liabilities altogether. ${ }^{23}$

To say that the AMT serves a function is not to say that on net it makes a worthwhile contribution to the tax system. There are many well-known costs of the AMT, notably including the complexity it introduces ${ }^{24}$ and its failure to permit taxpayers to benefit from (and be influenced by the availability of) deductions and credits that are otherwise deemed to be worthwhile. ${ }^{25}$ Many of the same criticisms might be leveled at an AMxT, though given the complexity of the regular income tax treatment of high-income taxpayers, it is likely that subjecting these taxpayers to an AMxT instead of the current tangled regime would actually make their situations less complex. It is, however, the case that an AMxT diminishes or removes incentives for affected taxpayers to engage in tax-preferred activities, which is costly from a social perspective, and which must be balanced against other benefits. This Article analyzes the role of the AMT in affording Congress the latitude to enact a progressive tax system

21 Mankiw, Weinzierl \& Yagan (2009, p. 147) (illustrating that dimensions of heterogeneity among taxpayers complicate the formation of an optimal tax rate structure).

22 Cf. Branham (2008-2009, p. 1509) (stating that Congress may be tempted to raise tax rates to compensate for decreased revenue due to tax evasion from overstated deductions).

23 It is difficult to know the extent to which the introduction of AMT-like tax provisions in the Internal Revenue Code starting in 1969 has been responsible for the subsequent persistence and growth of tax preferences. The U.S. Government Accountability Office (2005) reports that tax expenditures, a readily available (if flawed) measure of federal tax preferences, more than doubled in number and tripled in real dollar value between 1974 and 2004. The AMT may have encouraged this growth of tax expenditures, though it is also possible that it would have occurred in the absence of an AMT.

24 See Karlinsky (1995, p. 139) (noting that the American Tax Policy Institute convened a meeting of tax experts who concluded that the AMT was not meeting its intended policy goals, is overly complex, and is not readily administrable).

25 See Burman, Gale \& Rohaly (2003b, p. 174) (illustrating some deductions, exclusions and credits disallowed under the AMT). 
with tax preferences, and notes that this argument in support of the imposition of an AMT also supports the imposition of an AMxT.

From the standpoint of de novo tax design there are alternatives to the current, largely flat-rate, AMT, including the introduction of several AMT brackets designed to correspond roughly to tax brackets in the regular income tax. When combined with a multiple-bracket AMxT, such a system ensures that a taxpayer's average tax rate lies within a chosen range. An even more sophisticated tax system might instead feature income-triggered phased reductions of the benefits of tax deductions and credits. ${ }^{26}$ Such a system would incorporate AMT-like features into the regular income tax by gradually increasing tax liabilities as tax preference items grow relative to taxable income, particularly for higher-bracket taxpayers. The AMT, by contrast, denies taxpayers the benefits of deductions and thereby creates additional tax liabilities that appear abruptly as high taxable incomes and significant reliance on tax preference items push taxpayers off the regular income tax and onto the AMT. Similar abrupt transitions characterize a boilerplate version of an AMxT.

It is an interesting question why the USA adopted an AMT without an accompanying AMxT, though as will become apparent, developments in the regular income tax have had something of an AMxT flavor. Top personal income tax rates are now considerably lower than they were when the AMT was first introduced, and taxpayers lose the benefits of certain deductions and other tax preferences as their incomes rise. Another AMxT element of the current income tax is the standard deduction, the availability of which reduces the tax liabilities of some low- and moderate-income taxpayers while removing the benefits of some of their tax preference items-though this AMxT element is structured very differently than the more comprehensive AMxT considered here. A more complete understanding of the role of the AMT and AMxT has the potential to offer better guidance in the design of this part of U.S. tax policy.

\section{FEATURES OF THE AMT}

A U.S. taxpayer is required to pay the larger of his or her regular tax liability and minimum tax liability (I.R.C. $\$ 55(\mathrm{a})$ ). The minimum tax liability is calculated using a different rate structure than the regular tax, and applies to a different tax base (I.R.C. $\$ 55(b)(1)(A)(2013)$ ). The regular income tax currently has seven brackets, with tax rates that rise with income. For married couples filing jointly

26 See Baneman et al. (2011) (noting that the Obama administration proposed to limit the benefits of itemized deductions to 28 percent; for instance, when a high-income taxpayer in the 35 percent bracket takes a $\$ 100$ itemized deduction, such deduction would save the taxpayer only $\$ 28$ instead of \$35). 
in 2013 , the first $\$ 17,850$ of income is subject to a 10 percent tax rate, the next income up to $\$ 72,500$ is subject to a 15 percent rate, the next income up to $\$ 146,400$ is subject to a 25 percent rate, the next income up to $\$ 223,050$ is subject to a 28 percent rate, the next income up to $\$ 389,350$ is subject to a 33 percent rate, and the next income up to $\$ 450,000$ is subject to a 35 percent rate; and income above $\$ 450,000$ is subject to a 39.6 percent rate (I.R.C. $\$ 1$ (2013); Rev. Proc. 2013-15, 2013-5 I.R.B. 444 (2013)). By contrast, there are just two tax brackets under the AMT: a 26 percent tax rate applies to the first $\$ 179,500$ of income, and a 28 percent tax rate applies to income above $\$ 179,500$ (I.R.C. $\$$ 55(b)(1)(A) (2012) (as modified by Rev. Proc. 2013-15, 2013-5 I.R.B. 444 (2013)). Lest one be concerned that high AMT rates apply to low-income taxpayers, it is important to note that a significant amount of income earned by low- and middle-income taxpayers is exempt. A married couple is entitled to an exemption of $\$ 80,800$ in calculating AMT liability, and single individuals entitled to an exemption of $\$ 51,900$, effectively exempting from the AMT those with incomes below these levels (I.R.C. $\$ 55(\mathrm{~d})(1)$ (2012) (as modified by Rev. Proc. 2013-15, 2013-5 I.R.B. 444 (2013)). Legislation passed in 2013 further provides that these exemption amounts are indexed to inflation and thus, in the absence of subsequent legislation, presumably will rise each year (American Taxpayer Relief Act of 2012).

The AMT base differs from that under the regular income tax, largely by adding various preference items to taxable income as calculated under the regular income tax. These preference items include personal exemptions and the standard deduction, neither of which is permitted under the AMT, various itemized deductions, depreciation in excess of certain specified limits, and other income items (I.R.C. $\$ 56(\mathrm{a})$ and (b) (2012)). Taxpayers are not entitled to deduct state, local or foreign income and property taxes (unless these taxes are deductible in calculating adjusted gross income), (I.R.C. $\$ 56($ b)(1)(A)(ii) (2013)), nor are refunds of these taxes taxable under the AMT. $^{27}$ Miscellaneous itemized deductions (to the extent that they exceed 2 percent of adjusted gross income and are deductible under the regular tax) are likewise not permitted in calculating taxable AMT income. ${ }^{28}$ Medical expenses are deductible only to the extent that they exceed 10 percent of adjusted gross income, rather than the 7.5 percent threshold (until recently) under the regular income tax. Interest on acquiring and constructing a principal residence is deductible

27 See I.R.C. $\$ 111($ a) (2013) (excluding from gross income the amount of deductions that were recovered in the taxable year to the extent that the amount recovered did not reduce the amount of tax imposed). Since such taxes were not deductible pursuant to the AMT, a taxpayer subject to the AMT received no benefit from the refund, and therefore is not taxable on such refunds.

28 I.R.C. $\$ 56(b)(1)(A)(i)(2012)$. 
under the AMT, but interest on a home equity loan is deductible only to the extent that the loan is used for substantially rehabilitating the taxpayer's principal residence. Investment interest expense is deductible only against net investment income. It is, however, noteworthy that the limitation on itemized deductions of high-income taxpayers, found in I.R.C. $\$ 68$, does not apply to income calculated for AMT purposes. See generally I.R.C. $\$ 56(\mathrm{~b})$ (2013).

Income for AMT purposes is also calculated making numerous adjustments to calculated depreciation, all of which are fun to list. A portion of the depreciation deduction for property placed into service prior to 1987 is a tax preference item for AMT purposes, as is the extent to which percentage depletion exceeds adjusted basis (though there are special provisions for domestic crude oil and natural gas; (I.R.C. $\$ 57(a)(6)(2013)$ ). There are limitations on the deductibility of intangible drilling costs of oil companies (I.R.C. $\$ 56(a)(2)$ (2013)). Costs associated with maintaining or expanding the circulation of publications such as newspapers, which are deductible under the regular income tax, must be amortized over three years in calculating taxable income for AMT purposes (I.R.C. $\$ 56(b)(2)(A)(i)$ (2013)). Research expenditures for activities in which the taxpayer does not materially participate, and mining exploration and development costs, must be amortized over 10 years, rather than deducted as under the regular income tax (I.R.C. $\$ 56(\mathrm{a})(2)$, (b)(2)(A)(ii) (2013)). Expenditures on pollution control facilities must be depreciated rather than amortized over five years as under the regular income tax (I.R.C. $\$ 56(\mathrm{a})(5)(2013))$.

There are indeed other adjustments to income for AMT purposes. Interest on some tax-exempt private activity bonds, which is exempt under the regular income tax, is not exempt under the AMT (I.R.C. $\$ 56(b)(1)(C)(i i i)(2013)$ ). Seven percent of the gain excluded from the sale of qualified small business stock is a preference item and taxed under the AMT (I.R.C. \$57(a)(7) (2012)). Incentive stock options, which under the regular income tax are not taxable until exercised, generate taxable income to holders at the time that they become tradable or reasonably certain to accrue (I.R.C. $\$ 56(b)(3)$ (2012)). AMT taxpayers are not permitted to deduct losses from farming activity in which they are not material participants (I.R.C. $\$ 58(a)(2012)$ ). AMT taxpayers are not permitted to defer taxable income using the completed contract method of accounting. ${ }^{29}$ Deductible net operating losses cannot exceed 90 percent of taxable income for AMT purposes (I.R.C. $\$ 56(d)(1)(A)(2012)$ ).

29 See I.R.C. $\$ 56(\mathrm{a})(3)$ (2012) (requiring taxpayers subject to the AMT to use the percentage of completion method of accounting for long-term contracts). 
The rather large exempt amounts under the AMT are not available to highincome taxpayers, which is achieved by reducing exempt amounts over ranges of income. For married taxpayers, the AMT exempt amount is reduced by 25 percent of the amount that income for AMT purposes exceeds $\$ 153,900$, ultimately eliminating the exemption for married couples with more than $\$ 477,100$ of taxable income for AMT purposes (I.R.C. $\$ 55(\mathrm{~d})(3)$ (2012) (as modified by Rev. Proc. 2013-15, 2013-5 I.R.B. 444 (2013)). Since every dollar married taxpayers earn above $\$ 153,900$ reduces the exemption (which starts at $\$ 80,800$ ) by 25 cents, it follows that the exemption is entirely eliminated once income reaches $\$ 153,900+(4 \times \$ 80,800)=\$ 477,100$. This phased reduction effectively imposes an additional 7 percent marginal alternative minimum tax over the phase out range where taxpayers are subject to 28 percent AMT rates $(0.25 \times 0.28=0.07)$.

Portions of certain nonrefundable tax credits available under the regular income tax cannot be applied to reduce AMT liability. The affected tax credits include the general business credit, the foreign tax credit, the alternative motor vehicle credit, and the alternative fuel vehicle refueling credit. Other nonrefundable credits, such as dependent care credit, the credit for the elderly and disabled, the adoption credit, the child tax credit, the credit for interest on certain home mortgages, the nonbusiness energy property credit, and the residential energy efficient property credit are permitted insofar as a taxpayer's regular income tax liability exceeds the individual's minimum tax liability calculated without the foreign tax credit. Finally, individuals whose AMT liabilities are the product of timing items (such as depreciation adjustments), and who transition from being subject to the AMT in one year to being subject to the regular income tax in another, are entitled to claim credits against regular income tax liabilities for past AMT payments. ${ }^{30}$

What is the upshot of this complicated system of calculating AMT liability? In 2010, roughly four million U.S. taxpayers were subject to the AMT, with total AMT tax liabilities of $\$ 27.5$ billion. ${ }^{31}$ Presumably many other taxpayers who would otherwise have been subject to the AMT changed their investment plans or took other actions designed to avoid AMT liability, thereby incurring

30 I.R.C. $\$ 53$ (2012). However, after January 1, 2013, taxpayers can only use the prior year AMT tax credit to offset tax liability on regular income, and are not entitled to a refund of the excess amounts of the credit. See generally I.R.C. $\$$ 53(e) (2013) (containing no provision allowing a refundable amount of the prior year AMT tax credit after January 1, 2013).

31 Data on AMT liabilities of U.S. taxpayers in 2010 are reported by Bryan (2012, p. 44). This and the following paragraph summarize some of the information reported by Bryan. For example, Bryan indicates that 4,019,538 taxpayers owed AMT in 2010, with aggregate AMT liability of $\$ 27,460,515,000$. 
indirect AMT burdens in the form of reduced after-tax incomes. These indirect AMT burdens do not appear in tables of tax liabilities, but are nevertheless real.

The distribution of AMT liabilities reflects the structure of the tax together with the structure of the U.S. income distribution. Low- and middle-income taxpayers are largely not subject to the AMT, the 91.5 million returns with positive adjusted gross incomes of $\$ 50,000$ or less in 2010 paying a total of just $\$ 46$ million in AMT, and the 30.5 million returns with adjusted gross incomes between $\$ 50,000$ and $\$ 100,000$ paying just $\$ 209$ million. ${ }^{32}$ As incomes rise and the AMT exemptions phase out and dwindle relative to AMT income, and tax preference items rise, so too do AMT liabilities. Of the 1.9 million returns with adjusted gross incomes in the $\$ 250,000-\$ 500,000$ range, 1.7 million owed AMT, with an aggregate liability of $\$ 13.2$ billion, or close to half the national total, and more than 10 percent of the non-AMT liability of $\$ 125$ billion for that income group. At much higher income levels, the high top marginal tax rates under the regular income tax, together with limits on itemized deductions, impose burdens sufficient to prevent many high-income taxpayers from paying AMT. For example, of the 102,000 returns with adjusted gross income of $\$ 2$ million or more in 2010, only 26,000 owed AMT, and their aggregate AMT liability was just $\$ 3.0$ billion, a sizeable sum but less than two percent of this group's non-AMT liability of $\$ 159$ billion.

\section{CRITIQUES OF THE AMT}

Even from this thumbnail description it is easy to see why the AMT is widely criticized for the complexity it introduces into the federal income tax system (Shaviro 2001; National Taxpayer Advocate 2012). There are costs of recordkeeping as well as the time required, by taxpayers themselves or by their paid preparers, both to understand the complex AMT rules and to fill out the requisite returns, all of which costs are made worse by the fact that even those taxpayers who are not subject to the AMT are nevertheless required to calculate potential AMT liability just in case they would be. ${ }^{33}$ These costs of ex post

32 Despite the high AMT exemption level it is entirely possible for taxpayers with modest adjusted gross incomes to be subject to the AMT, since the income calculation for AMT purposes denies personal exemptions, standard deductions, and numerous other deductions, and includes income items that are excluded under the regular income tax. The data reported by Bryan indicate that 17,803 taxpayers with positive adjusted gross incomes below $\$ 50,000$ in 2010 were subject to the AMT, as were 6330 taxpayers with no adjusted gross income. $I d$.

33 Treasury and IRS economists estimate that, in 2000, U.S. taxpayers spent 18.4 million hours complying with AMT filing requirements, representing more than 12 hours for each taxpayer who paid the AMT, and a substantial portion of the 22 hours that Form 1040 was estimated to require (Lerman \& Lee 2005). The subsequent more ready availability and use of tax preparation software 
"computational complexity" are not trivial, although they are reduced insofar as the AMT calculation can readily be programmed into tax-preparation software used by tax preparers or by individual taxpayers themselves. Such programs automatically calculate the taxpayer's regular income tax and AMT tax liabilities simultaneously, and require relatively little expertise or time on the part of the person entering the data. ${ }^{34}$ Tax-preparation software is less helpful, however, in reducing the costs of ex ante "transactional complexity" faced by taxpayers who must figure out the AMT rules in order to plan their future transactions (Bradford 1986).

Another critique occasionally made of the AMT is that the resulting aggregate tax burdens do not have as strong a counter-cyclical effect as do tax burdens under the regular income tax (e.g., Shaviro 2001; Listokin 2011). ${ }^{35}$ Regular income tax burdens rise sharply during economic expansions, as taxpayers not only have greater incomes but their rising incomes are taxed at increasing rates; this is particularly true among those in upper tax rate brackets receiving profit-style income, which increases most dramatically during economic expansions. To the extent that higher personal taxes reduce income and thereby discourage consumption, and that consumption contributes to aggregate demand that stimulates the economy, then it follows that a progressive personal income tax system offers an automatic stabilizer that reduces the amplitude of economic cycles. If the AMT reduces the progressivity of the income tax then by this argument it presumably also reduces its countercyclical impact.

In addition to the costs of complexity and the possible pro-cyclical effects of the AMT are the efficiency costs associated with the AMT rates themselves. It is now well understood that high marginal income tax rates can create inefficient work and investment incentives. High marginal tax rates depress the production of taxable income by encouraging early retirement, reducing work effort of primary and secondary earners, and giving taxpayers incentives to pursue investments and other opportunities that reduce taxable income (Rosen 1980;

has very likely reduced these compliance costs, though the record keeping alone may impose a substantial burden.

34 Some regard the lowering of compliance costs associated with the rise of TurboTax and the like to be a bad thing, because the complexity of the tax laws ends up being hidden from voters, ultimately leading to greater complexity (Gleckman 2012).

35 However, some scholars have suggested that the federal AMT can have counter-cyclical or stabilizing effects for the economy overall, once state tax collections are taken into account (Galle \& Klick 2010). The idea is that, in good times when incomes are high and states are collecting lots of revenue, more individual taxpayers are hit by the federal AMT, which means more people lose the federal deduction for state and local taxes, which in turn reduces the federal subsidy for state and local governments. During bad times, the reverse tends to happen, or so it is argued. 
Saez, Slemrod \& Giertz 2012). And those distortions will be made worse whenever the AMT imposes higher marginal rates than does the regular income tax. This will be true for parts of the income range where the marginal tax rates created by the AMT exceed those to which the regular income tax apply. The high-marginal rates in this income range reflect the rather large exempt amounts together with an unwillingness to permit higher-income taxpayers to benefit from them. Obviously these inefficiencies are relevant only to those taxpayers who might possibly be subject to the AMT, which largely excludes low- and middle-income taxpayers. The phase out range of the exempt amount under the AMT is responsible for a 32.5 percent $(0.065+0.26=0.325)$ marginal tax rate for married AMT taxpayers with incomes between $\$ 153,900$ and $\$ 179,500$, and a 35 percent $(0.07+0.28=0.35)$ marginal rate for those with incomes between $\$ 179,500$ and $\$ 477,100$. While differences in taxable income definitions make direct comparisons difficult, marginal rates are generally higher under the AMT than under the regular income tax for many taxpayers in these phaseout ranges. ${ }^{36}$

In addition to its general effects on incentives to earn income, the AMT discourages certain taxpayers from accumulating preference items that trigger additional AMT liability. To the extent that there are sound efficiency reasons for these preference items to receive favorable tax treatment, then the removal of some of the potential tax benefits inefficiently discourages their use. If Congress adjusts the value of preference items to maintain, for example, an efficiently sized aggregate market for private activity municipal bonds, then the imposition of AMT liability on holders of these bonds inefficiently distorts portfolio allocation across individuals, whatever may be the effect of the tax on aggregate levels of private activity supported by municipal bonds.

On top of these criticisms of the AMT on complexity and efficiency grounds, the AMT has been criticized for lacking a coherent purpose. As discussed more fully in the next section, the AMT was designed at least in part to reduce the number of high income taxpayers who pay little or no federal taxes, which the AMT has in fact done: although there remain some high-income taxpayers who in a given year owe no federal income tax, there are fewer than there would be in the absence of the AMT. ${ }^{37}$ It is difficult to know why this particular function of

36 Analysis of actual and projected AMT and regular income tax liabilities as of 2003 suggests that, in that era, the AMT increased marginal tax rates in certain taxpayer circumstances reduced marginal rates in others. Overall the AMT had only a modest effect on aggregate marginal tax rates, appearing to increase them slightly. See Feenberg \& Poterba (2004).

37 One study estimates that, in 2001, 109 U.S. taxpayers with adjusted gross incomes over \$1 million owed no federal income tax that year, despite the AMT (Burman et al. 2002). The study also estimates, however, that had the AMT not been in place that year 732 U.S. taxpayers with adjusted gross incomes over \$1 million would have had no federal income tax liability. 
the AMT would be considered particularly important, since there are many apparent tax liability inequities at all income ranges, making it curious that attention focuses on the zero measured effective tax rates of a handful of affluent taxpayers. ${ }^{38}$ Furthermore, high-income taxpayers who have zero regular income tax liabilities typically have rather special situations that in fact entail substantial federal tax burdens, however nontransparent they may be from the perspective of one year's tax remittance. For example, such taxpayers might have significant net operating loss carry-forwards from previous years, significant federal tax obligations in other years due to quirks or planning in the timing of income recognition, income from tax-exempt bonds that pay low market interest rates due to their tax exemptions, or other individual tax situations that do not correspond to an absence of federal tax burdens. Individuals who alter their activities to avoid heavily taxed investments and other opportunities typically incur costs that can be viewed as implicit taxes. In such situations, a single-year picture of the taxpayer's income tax liability can be especially misleading. In addition, if the design of the AMT reflects a desire to prevent excessive tax avoidance, then tax provisions that permit avoidance might reasonably be abandoned or reduced in significance for everyone, rather than selectively removing them for a small group of taxpayers whose liabilities fall below acceptable thresholds.

\section{A MORE COMPREHENSIVE UNDERSTANDING OF THE AMT, And Of An AMxT}

Given these and other critiques, it is obvious that the existing AMT is hardly the product of optimal design. Nevertheless, it is possible to offer a coherent rationale for imposing some form of AMT to accompany the regular income tax. Importantly, this rationale also supports the imposition of an Alternative Maximum Tax, or AMxT. As mentioned in the introduction, this rationale builds on the notion that tax policymakers, and the electorate they represent, wish to use the income tax system to achieve two goals: to raise revenue in a manner that distributes individual tax burdens progressively, with average tax rates that rise with individual incomes, and to encourage particular types of activities that provide special social benefits. These two goals can conflict with each other, insofar as the ability or inclination to take advantage of

38 This critique was perhaps best articulated by Daniel Shaviro as follows: "[I]t is is hard to see why a decline in the nominal rate from 20 percent to 0 percent should raise greater concern than a decline from 40 percent to 20 percent when, 'in simple arithmetical terms, each equal percentage step in the reduction of one's tax liabilities has the saqme effect on revenues, no matter what the starting or stopping point.'” Shaviro (2001, p. 1460), quoting Shaviro (1988). 
tax preferences varies across individual taxpayers - that is, when there are both tax-preference preferers and tax-preference nonpreferers. Moreover, the conflict can occur when the preferers and nonpreferers have the same or when they have very different levels of economic income. And it is this conflict that provides the rationale for the AMT. The function of the AMT is to permit some use of tax preferences (at the expense of progressivity values) but at some point to limit the use of those preferences (in protection of progressivity values). Although society is willing to sacrifice some degree of progressivity in the interest of creating incentives, the AMT serves as a sort of insurance against excessive sacrifice of progressivity.

This justification for the AMT is best understood through an example that starts with two hypothetical taxpayers, A and B. Taxpayer A has net taxable income of $\$ 300,000$ as defined under the regular income tax. Taxpayer B has net taxable income of $\$ 30,000 .^{39}$ This regular income tax has the following graduated rates: 15 percent on income up to $\$ 40,000 ; 35$ percent on income between $\$ 40,000$ and $\$ 150,000$, and 50 percent on any income above $\$ 150,000$. This is clearly a progressive tax system, in that average tax burdens rise with income. Suppose that the government offers a single tax preference, say, an unlimited charitable deduction, that is intended to encourage individuals to contribute to charities, thereby improving society and reducing the need for government to undertake some of the activities performed by charities. ${ }^{40}$ Suppose that only taxpayer A has a preference for, and therefore does make, charitable contributions, contributing $\$ 200,000 /$ year and thereby reducing A's taxable annual income to $\$ 100,000$. Taxpayer $\mathrm{A}$, then, is the tax-preference preferer. The availability of a deduction for charitable contributions reduces A's income tax liability considerably, producing the following schedule of tax payments and effective tax rates (defined as the ratio of tax liability to income) (Table 1).

39 For simplicity, the examples in the text ignore personal exemption deductions. There are good arguments for permitting personal exemption deductions generally in calculating taxable income, and for permitting the same personal exemption deductions under an AMT regime and under an AMxT regime. Under the existing AMT regime, however, personal exemption deductions are, inexplicably, treated as tax preferences-meaning the deductions are permitted for purposes of calculating regular tax liability but not for purposes of calculating alternative minimum tax liability.

40 This Article treats the charitable contribution deduction as if it were a quintessential example of a tax preference-a provision in the tax code designed to encourage a particular type of investment. Some might contend that the charitable deduction is necessary to a proper calculation of net income. To the extent that is persuasive, the charitable deduction arguably should not be treated as a tax preference at all; and hence differences in tax liability attributable to differences in charitable giving might be consistent with progressivity norms. Deciding which deductions, exemptions, and the like should be treated as a tax preference is another of the complexity costs associated with using an AMT or an AMxT - and is a task that is beyond the scope of this article. In this context it is noteworthy that the charitable deduction is not a tax preference in the current AMT. 
Table 1. Effective Tax Rates with No AMT: Disparity between High-Income Preference Preferer and Low-Income Non-Preferer

\begin{tabular}{lllll}
\hline Taxpayer & Income & Charitable contribution & Income tax liability & Effective tax rate \\
\hline A & $\$ 300,000$ & $\$ 200,000$ & $\$ 27,000$ & $9 \%$ \\
B & $\$ 30,000$ & $\$ 0$ & $\$ 4500$ & $15 \%$ \\
\hline
\end{tabular}

Table 2. Effective Tax Rates with AMT: Disparity Reduced

\begin{tabular}{|c|c|c|c|c|}
\hline Taxpayer & Income & $\begin{array}{l}\text { Charitable } \\
\text { contribution }\end{array}$ & $\begin{array}{l}\text { Regular tax liability/ } \\
\text { (effective tax rate) }\end{array}$ & $\begin{array}{l}\text { AMT liability/ } \\
\text { (effective tax rate) }\end{array}$ \\
\hline$A$ & $\$ 300,000$ & $\$ 200,000$ & $\$ 27,000 /(9 \%)$ & $\$ 67,500 /(22.5 \%)$ \\
\hline B & $\$ 30,000$ & $\$ 0$ & $\$ 4500 /(15 \%)$ & $\$ 0 /(0 \%)$ \\
\hline
\end{tabular}

If one makes the (admittedly contestable) assumption that the charitable contribution deduction is a tax preference, the conflict between progressivity and investment incentives is reflected in the difference between the tax treatments of taxpayers A and B. Taxpayer A has considerably greater resources than taxpayer B, yet pays a lower effective tax rate (albeit more in total taxes) due to A's ability to benefit from the charitable deduction. Of course, some sacrifice in progressivity between $A$ and $B$ is inevitable in a world in which $A$ is a charitablededuction preferer and $\mathrm{B}$ is not, as in this example. But a society concerned with progressivity might sensibly place an upper limit on the degree of progressivity it is willing to sacrifice by using tax preferences to encourage socially desirable behavior. The AMT offers one method of doing so.

Consider, in this example, an AMT with a 25 percent rate on all income, defined without a deduction for charitable contributions, but with an exclusion for the first $\$ 30,000$ of taxable income. The taxpayer owes the higher of the regular income tax and AMT liability. The resulting distribution of tax burdens is as follows (with the taxpayer's ultimate tax highlighted in bold) (Table 2).

Taxpayer A is subject to the AMT and is required to pay tax equal to 22.5 percent of income defined broadly. Taxpayer B continues to pay only the regular income tax liability, with an effective tax rate of 15 percent. The resulting distribution of the income tax burden is arguably more consistent with progressive income tax principles (taking charitable contributions to be equivalent to other spending), given that A's economic income exceeds B's. Of course, this increase in A's effective tax rate presents all of the complexity and efficiency problems discussed in the previous part. The administrative and efficiency costs associated with the AMT are simply components of the overall cost of raising 
Table 3. Effective Tax Rates with AMT But No AMxT: Disparity between High-Income Preference Preferer and High-Income Non-Preferer

\begin{tabular}{lllll}
\hline Taxpayer & Income & $\begin{array}{l}\text { Charitable } \\
\text { contribution }\end{array}$ & $\begin{array}{l}\text { Regular tax liability/ } \\
\text { (effective tax rate) }\end{array}$ & $\begin{array}{l}\text { AMT liability/ } \\
\text { (effective tax rate) }\end{array}$ \\
\hline A & $\$ 300,000$ & $\$ 200,000$ & $\$ 27,000 /(9 \%)$ & $\$ \mathbf{6 7 , 5 0 0 / ( 2 2 . 5 \% )}$ \\
B & $\$ 30,000$ & $\$ 0$ & $\$ 4500 /(\mathbf{1 5} \%)$ & $\$ 0 /(0 \%)$ \\
C & $\$ 300,000$ & $\$ 0$ & $\$ 119,500 /(39.8 \%)$ & $\$ 67,500 /(22.5 \%)$ \\
\hline
\end{tabular}

tax revenue in a progressive manner, which governments presumably weigh against the benefits of progressivity.

The same progressivity-policing argument supports imposing not only lower limits on the tax liabilities of tax-preference preferers, but also upper limits on the tax liabilities of individuals who are tax-preference nonprefers. To illustrate the workings of an alternative maximum tax (or AMxT), it is helpful to consider the situation of an additional hypothetical Taxpayer $\mathrm{C}$ who, like Taxpayer A, earns $\$ 300,000$ in regular income, but who differs from A in not giving anything to charity. Recall that under the AMT, the taxpayer pays the higher of AMT or regular tax liability, shown below in bold; Taxpayer C, who chooses not to give to charity, and therefore has no tax preferences, will not be subject to the AMT.

Columns 4 and 5 of Table 3 illustrate the progressivity of this tax system. Introduction of the AMT increases A's effective tax rate from $9 \%$ to $22.5 \%$, thereby raising it above B's effective tax rate of $15 \%$, but leaving A with a much lower effective tax rate than C $(39.8 \%)$, even though A and C have the same economic income. Put differently, C's unwillingness to contribute to charity leaves $\mathrm{C}$ with a much higher effective tax rate than $\mathrm{A}$, despite their equal economic resources.

The AMxT adjustment is a mirror image to that of the AMT. An AMxT can be designed to use the same tax base as the AMT, but impose a rate of, say, 35 percent on all AMxT income, with an exclusion for the first $\$ 30,000$. With both an AMT and an AMxT in place, a taxpayer pays the lower of the AMxT liability, on the one hand, and the higher of the AMT liability or the regular tax liability, on the other. Put differently, the taxpayer owes the regular tax amount if it lies between the AMT and AMxT liabilities. If the regular tax amount is below the AMT liability then the taxpayer pays the AMT; if the regular tax amount exceeds the AMxT liability then the taxpayer pays the AMxT. These calculations are simplified by the feature that, since the AMxT uses the same tax base as the AMT and imposes a higher rate, the AMxT liability must exceed the AMT liability. The distribution of tax burdens with both an AMT and an AMxT is given in Table 4, with ultimate tax liability highlighted in bold. 
Table 4. Effective Tax Rates with Both an AMT and an AMxT: Both Disparities Reduced

\begin{tabular}{llllll}
\hline Taxpayer & Income & $\begin{array}{l}\text { Charitable } \\
\text { contribution }\end{array}$ & $\begin{array}{l}\text { Regular tax / } \\
\text { (effective rate) }\end{array}$ & $\begin{array}{l}\text { AMT / } \\
\text { (effective rate) }\end{array}$ & $\begin{array}{l}\text { AMxT / } \\
\text { (effective rate) }\end{array}$ \\
\hline A & $\$ 300,000$ & $\$ 200,000$ & $\$ 27,000 /(9 \%)$ & $\mathbf{\$ 6 7 , 0 0 0 / ( 2 2 . 5 \% )}$ & $\$ 94,500 /(31.5 \%)$ \\
B & $\$ 30,000$ & $\$ 0$ & $\$ \mathbf{4 5 0 0 / ( 1 5 \% )}$ & $0 /(0 \%)$ & $0 /(0 \%)$ \\
C & $\$ 300,000$ & $\$ 0$ & $\$ 119,500 /(39.8 \%)$ & $\$ 67,000 /(22.5 \%)$ & $\$ \mathbf{9 4 , 5 0 0 / ( 3 1 . 5 \% )}$ \\
\hline
\end{tabular}

This tax system imposes a combination of AMT and AMxT that reduces the difference in effective tax rates between $\mathrm{A}$ and $\mathrm{B}$, and also reduces the difference between $\mathrm{A}$ and $\mathrm{C}$. In the absence of the AMT and AMxT taxpayer A faces an effective tax rate of $9 \%$ and taxpayer $\mathrm{C}$, with the same economic income, faces an effective tax rate of $39.8 \%$. The AMT increases A's effective tax rate to $22.5 \%$ and the AMxT reduces C's effective tax rate to $31.5 \%$, reducing the disparity by more than two thirds, though not eliminating it. In this example the combination of the AMT and the AMxT limits the extent to which tax preference availability undermines overall tax progressivity.

Introduction of an AMT and AMxT entails sacrificing some of the incentive effects of tax preferences, represented in the example by the charitable deduction. Taxpayer A, for example, would no longer benefit to the same extent from the availability of charitable deductions. Indeed, one consequence of taxpayer A's AMT status is that a small change in charitable deductions would not change taxes owed. Greater charitable deductions would not reduce A's taxes, since A would remain subject to the AMT; and A would need to reduce charitable deductions by more than $\$ 95,000$ before incurring a regular tax liability that exceeds the $\$ 67,000$ owed under the AMT. As a result, the charitable deduction, the availability of which reduced A's tax liability from $\$ 94,500$ (under the AMxT) to $\$ 67,000$ (under the AMT), does not stimulate additional charitable contributions at the margin; only the first $\$ 105,000$ of charitable deductions had any effect on A's tax liability, and of that, the first $\$ 50,000$ had no effect, since with charitable contributions below $\$ 50,000$ A would have been subject to the AMxT.

The imposition of an AMT therefore can be expected to reduce A's incentives to contribute to charity, and thereby reduce total contributions. A similar logic applies to AMxT taxpayers, whose tax obligations are unaffected by changes in charitable contributions as long as contributions are small enough that taxpayers remain subject to the AMxT. In the example, $\mathrm{C}$ would need to contribute more than $\$ 50,000$ before being subject to the regular income tax rather than the AMxT, so if C's desired contributions fall in this range, then the potential availability of tax preferences would not influence C's contribution level. Hence 
the imposition of an AMxT likewise should be expected to reduce charitable contributions, a consideration that is part of the efficiency tradeoff that a rational government would make in choosing AMT and AMxT bases and rates.

The last example illustrates the general point that an AMxT reduces the stimulatory effects of tax preferences only for those taxpayers who take the least advantage of them. Presumably the relevant activities of these taxpayers are less price-sensitive than they are for other taxpayers, which is why they do so little despite the potential availability of tax benefits. If the government in offering tax benefits for socially desirable activities (such as charitable giving) trades off the benefits of encouraging the activities against the equity consequences of tax reductions, then it is cost-effective to target benefits to taxpayers whose behavior is most apt to be affected, which an AMxT does by providing its tax relief only to the relatively unresponsive taxpayers. It is nonetheless inefficient not to offer incentives to taxpayers subject to an AMxT, but less than it would be to remove incentives from average taxpayers of the same income levels. It is noteworthy in this context that the AMT has exactly the opposite properties, removing incentives from taxpayers who do the most tax-preferred activities, and who are therefore presumably the most responsive to incentives.

While very different in appearance, the AMxT serves a function that is perfectly analogous to that served by the AMT. One noteworthy aspect of the history of the AMT is that the original justification for the AMT included its role in protecting the ability of Congress to maintain the progressivity of the income tax while granting preferential treatment to certain activities. A second aspect is that a form of AMxT was a central piece of the original proposal. And a third aspect is that Congress has struggled to settle on an AMT regime that it finds fully satisfactory from the standpoint of revenue generation and taxpayer equity. It is possible that the introduction of an AMxT to accompany the AMT might give Congress tax policy options that would prove more stable in the long run.

\section{ORIGINS OF THE AMT (And The AMxT)}

The modern AMT first appeared as part of the Tax Equity and Fiscal Responsibility Act of 1982, though its origins lie years earlier. Senator Russell Long, who was the powerful longtime chair of the Senate Finance Committee, proposed a form of AMT in October 1963 as an ultimately unsuccessful amendment to the legislation that became the 1964 tax reform (Bittker 1965-1966). Senator Long reintroduced this legislation with modifications in 1964 and again in January 1966 (Traeger 1967). In that era the top personal income tax rate was 70 percent, having recently (1964) been reduced from 91 percent. Long 
proposed that taxpayers be entitled to elect to be subject to a modified income tax system with fewer deductions and credits, and a modified rate structure with a maximum 50 percent tax rate. The election under the original Long proposal would be binding for five years. ${ }^{41}$ Personal deductions, whether itemized or the standard deduction, would not be permitted in calculating taxable income, and the favorable treatment of capital gains (which in that era took the form of excluding 50 percent of capital gains from taxable income) would be eliminated. Contributions to qualified pension plans would no longer be deductible for employers, nor would state, local, and foreign income and property tax payments be deductible for individuals. The proposal would change the method of calculating deductible expenses under I.R.C. $\$ 212$, require capitalization and amortization of publication circulation expenses, agricultural conservation expenses, and certain other investment-type expenditures then fully deductible. The proposal would reduce the tax benefits associated with percentage depletion and intangible drilling and development costs. Taxable income would include two-thirds of Social Security benefits, the non-gift portion of scholarships and fellowships, and certain death benefits and sick pay.

In short, though several of the details differ substantially, the taxable income definition in the Long proposal from the early 1960s, though never enacted, bears a close resemblance to that in the AMT today. The systems nevertheless differ dramatically in their implications, in that the optional election in the Long proposal effectively makes it an alternative maximum tax, capping potential tax liabilities, whereas the AMT puts a floor under potential tax liabilities.

Senator Long advanced two arguments in favor of his proposal. The first was that it afforded a simplified tax calculation that would spare taxpayers time, energy, and anguish. Presumably these personal benefits were to accrue during the four years between election dates, since the optional nature of the Long system rewards taxpayers who calculate their tax liabilities two ways, carefully forecast their future income and deduction streams under both systems, and choose the one that is most advantageous. As contemporary observers noted, this was far from simple, despite the apparently more straightforward process of calculating taxable income under a system with fewer preferences (Bittker 1965-1966, pp. 31-36).

The second justification offered by Senator Long was that the simplified system would reduce inequities in the distribution of tax burdens. Relying on

41 Senator Long's 1964 version would have permitted a taxpayer to revoke subsequently an election to be subject to the alternative tax, although the revocation would necessarily apply to all five years, not single years selectively, and would trigger a 5 percent penalty in addition to back taxes and interest (Bittker 1965-66, p. 10). 
unpublished Treasury analysis for tax year 1959, Senator Long reported that effective tax rates among the 1002 tax returns with adjusted gross income of $\$ 500,000$ or higher ranged from zero to 85 percent. Twenty of these returns, including five with adjusted gross incomes exceeding $\$ 5$ million, paid zero federal income tax, while 56 paid total tax equivalent to more than 70 percent of their incomes. The average liability among these high income returns was 46 percent of income (Traeger 1967). Senator Long's proposal would not affect high-income taxpayers with very little regular income tax liability, who would generally elect to continue with the regular income tax system that treats them so kindly, ${ }^{42}$ but would have addressed some of the inequities among the highest income taxpayers.

The Long proposal, and accompanying discussion of apparent tax rate disparities among high-income taxpayers, struck a chord with many legislators despite its failure to become law. The very high marginal tax rates of that era led to perceived excessive use of tax preferences by some, though by no means all, taxpayers. With a top marginal rate of 91 percent until 1964, and a still substantial 70 percent top marginal rate thereafter, some taxpayers became quite savvy about the opportunity to benefit from tax planning opportunities. These benefits, while sufficient to influence taxpayer behavior, are likely quite a bit smaller than they at first appear, since a substantial portion of the apparent tax avoidance consisted of the light taxation of sources of income such as investment returns that were depressed by virtue of their tax-favored status, and thereby effectively embodied implicit taxes at rates perhaps not much below that which taxpayers would pay in the absence of avoidance. Despite this subtlety, the range of reported tax liabilities for taxpayers with similar adjusted gross incomes remained a source of concern to Senator Long and other legislators.

Congress never enacted Senator Long's proposal, though it influenced provisions of the Tax Reform Act of 1969 (TRA 69). The TRA 69 was a product of changing Washington politics and unusually heavy Congressional tax activism. At the close of the Johnson administration in January 1969 the U.S. Treasury completed a comprehensive study of potential reforms to the income tax. This study (U.S. Treasury Department 1969), spearheaded by Assistant Secretary Stanley Surrey and heavily influenced by his concept of an appropriate tax

42 There were potential exceptions. One exception was that high-income taxpayers who would benefit from the simplified alternative proposed by Senator Long would presumably elect it even though there might be some years in which their regular income tax liabilities would be zero under the regular income tax and positive in Senator Long's system. Another exception is that high-income taxpayers who incur sufficient costs in undertaking activities to avoid taxes might fare better by electing the optional alternative, paying more in tax, and nonetheless emerging with greater after-tax incomes. 
base, included several reform recommendations. The study itself was the product of years of work by the Treasury staff, and its formation and release to Congress was requested by the 1968 Revenue and Expenditure Control Act and subsequent requests bordering on demands by chairs of the House and Senate tax writing committees (Wilbur Mills and Russell Long). ${ }^{43}$ The Johnson administration declined to transmit the study to Congress, instead passing it off to the incoming Nixon administration, which, in contrast with later developments, immediately and rather meekly complied with the Congressional request. ${ }^{44}$

The Treasury study recommended that Congress enact both an alternative minimum tax and an alternative maximum tax. The minimum tax would be applied to a tax base that included all realized capital gains (rather than only 50 percent, which was then the prevailing treatment), ${ }^{45}$ interest on state and local government bonds, and did not permit deductions for percentage depletion in excess of basis and charitable gifts of appreciated property where the appreciation is not recognized as income. The tax rates under the minimum tax would range from 7 to 35 percent, representing half the rates then applicable to individuals. Married couples with incomes below $\$ 10,000$, and individuals with incomes below $\$ 5,000$, would be exempt from the minimum tax.

The Treasury also proposed that Congress enact an alternative maximum tax. Its AMxT base would be computed in the same manner as the AMT base, and the AMxT rate would be 50 percent. Thus, under the Treasury proposal, every taxpayer would owe taxes equal to between 7 and 50 percent of his or her alternative taxable income, the ultimate rate being a function of income level and whether the taxpayer was taxable under the regular tax, the AMT, or the AMxT.

The Treasury report justified its recommendations on the two grounds used by Senator Long years earlier, though the report devotes little attention to the possible simplification benefits of the AMT and AMxT combination, instead focusing on fairness in the distribution of tax burdens. The report documents wide disparities in effective tax rates within income groups, particularly the very

43 Section 110 of the Revenue and Expenditure Control Act of 1968 provides that "the President is to submit to the Congress proposals for a comprehensive reform of the Internal Revenue Code of 1954" (U.S. Congress Conference Committee (1968, p. 21).

44 The Nixon administration transmitted the Treasury study and recommendations in late January 1969. Later that year, in April 1969, the Nixon administration released its own tax reform proposal.

45 Instead of excluding half of realized capital gains from taxable income, taxpayers in that era could elect an alternate treatment in which realized capital gains were taxed at 25 percent regardless of a taxpayer's marginal tax rate. Graetz \& Sunley (1988, p. 412) characterize the Treasury's minimum tax proposal as "largely a backdoor means of increasing the maximum tax rate on capital gains to 35 percent," and identify Stanley Surrey as the driving force behind this proposed reform. 
wealthy, based on analyses of tax returns for 1958-1961 and 1964 (U.S. Treasury Department 1969, pp. 79-94) ${ }^{46}$ and projects that, for tax year 1969, the proposed reforms would reduce effective tax rate disparities within all income deciles (id, 98).

Release of the Treasury report, and its evidence that some high-income individuals paid no federal tax, triggered activity in Congress that led ultimately to passage of the TRA 69. This legislation embodied several of the Treasury recommendations, though notably not its AMT and AMxT provisions. Instead, the TRA 69 imposed a new 10 percent tax on certain tax preference items, including interest expense in excess of net investment income, depreciation in excess of straight line for real property and for personal property subject to a lease, amortization of rehabilitation expenditures in excess of straight line depreciation, amortization of certified pollution control facilities and railroad stock in excess of accelerated depreciation, the difference between the value of qualified stock options and their option prices at the time of exercise, depletion deductions in excess of basis, and the excluded 50 percent of realized capital gains. Taxpayers were entitled to deduct regular tax payments from preference items in calculating amounts subject to the 10 percent tax.

The TRA 69 also made gestures in the direction of an AMxT by reducing the maximum average tax rate on earned (largely wage and salary) income from 70 percent to 50 percent, while retaining a maximum marginal tax rate of 70 percent for other income. The accompanying explanation from the Joint Committee on Taxation notes the benefits of reducing tax planning activity and disincentives to earn income by reducing the rate to 50 percent, though omits discussion of any possible fairness advantages that might stem from this limitation on average tax burdens (U.S. Congress Joint Committee on Taxation 1970, pp. 224-225).

Congress subsequently modified details of its tax on preference items in legislation enacted in 1970, 1971, 1976, 1977, 1978, and 1981; and the Tax Reform Act of 1976 also increased the tax rate on preference items to 15 percent. Importantly, the Revenue Act of 1978 added the first alternative minimum tax, calculated by applying generally low rates (the top tax rate was 25 percent, subsequently reduced to 20 percent in the Economic Recovery Tax Act of 1981) to a modified definition of income equal to regular taxable income plus excluded capital gains and certain itemized deductions. Taxpayers owed either the alternative minimum tax or the sum of regular income tax plus the tax on preference items, whichever was greater. This modification thereby 
prevented taxpayers with extensive itemized deductions and income largely in the form of capital gains from facing only the very low surtax rate.

The modern version of the AMT was introduced by the Tax Equity and Fiscal Responsibility Act of 1982, which simultaneously repealed the tax on certain preference items introduced by TRA 69, adding these preferences, with some others, to the list of items added back to taxable income in calculating alternative minimum tax liabilities. The 1982 AMT rate was 20 percent, applied to AMT income in excess of $\$ 40,000$ ( $\$ 30,000$ for unmarried taxpayers). AMT income was calculated without deductions for state and local taxes, personal exemptions, the standard deduction, or interest on home equity loans; furthermore, gains on incentive stock options were taxable under the AMT. Nonrefundable tax credits other than the foreign tax credit were not allowed to be applied against AMT liabilities. Importantly, the AMT bracket amount$\$ 40,000$ in the case of married couples-was not indexed to inflation, even though individual tax brackets in the regular income tax were indexed to inflation. The result of nonindexing of the AMT was that increasing numbers of individuals would owe AMT over time as nominal incomes rose and the value of the $\$ 40,000$ exemption shrank in real terms. The Joint Committee on Taxation in 1982 explained that Congress "amended the present minimum tax provisions applying to individuals with one overriding objective: no taxpayer with substantial economic income should be able to avoid all tax liability by using exclusions, deductions, and credits. Although these provisions provide incentives for worthy goals, they become counterproductive when individuals are allowed to use them to avoid virtually all tax liability." (U.S. Congress Joint Committee on Taxation 1983, p. 17).

The Tax Reform Act of 1986, which made many changes to the regular income tax, also increased the AMT rate to 21 percent. The AMT exemption amount was phased out for married couples with AMT income above $\$ 150,000$ ( $\$ 112,500$ for unmarried taxpayers), and taxpayers were no longer entitled to deduct interest on private activity bonds and were taxed on appreciation of property contributed to charity. Net operating losses were allowed to offset only 90 percent of AMT income and the foreign tax credit restricted not to reduce AMT liabilities by more than 90 percent. In legislation since 1986 the AMT tax base has been changed by repealing the preference for charitable contributions of appreciated property, repealing the preference for percentage depletion on oil and gas wells, substantially reducing the amount of the preference for intangible drilling expenses, and repealing the requirement that alternative depreciation lives be used in computing the deduction for ACRS depreciation (used for property placed in service between 1981-1986).

Tax legislation in 1990 increased the AMT rate to 24 percent while also increasing the maximum individual tax rate from 28 to 31 percent. In 1993 
the current 26 and 28 percent AMT rate structure was introduced, along with higher regular income tax rates that peaked at 39.6 percent. Legislation in 1997 conformed the AMT capital gain rates to the lower capital gain tax rates adopted for the regular tax, and 2003 legislation conformed AMT rates for dividend income to the lower rates adopted for the regular tax.

Congress has increased AMT exemption levels over time, passing legislation in 1993 that increased the AMT exemption levels to $\$ 45,000$ for married couples and $\$ 33,750$ for unmarried individuals. From 2001-2012 Congress enacted temporary increases in AMT exemption levels and thereby provided tax relief while avoiding the sudden large costs over its 10-year budget window that would accompany a permanent increase in the exemption. For 2001 and 2002 these levels were increased to $\$ 49,000$ for a married couple and $\$ 35,750$ for an unmarried individual; in 2003-2005 the levels were $\$ 58,000$ for a married couple and $\$ 40,250$ for an unmarried individual; this process culminated with 2012 exemption levels of $\$ 78,750$ for a married couple and $\$ 50,600$ for an unmarried individual. As noted earlier, legislation passed in January 2013 provides that the 2012 exemption levels are permanent, and indexed to inflation (so that for 2014 they are $\$ 82,100$ for a married couple and $\$ 52,800$ for an unmarried individual).

\section{MINIMUM AND MAXIMUM TAXES AND OPTIMAL TAX THEORY}

Does it make sense as a policy matter to have an individual income tax system of which an important component is an AMT and an AMxT? This Article maintains that the most coherent and compelling case for adopting some form of AMT and AMxT rests on the claim that together they permit lawmakers to trade off two conflicting objectives: implementing a progressive income tax system and using tax preferences to encourage certain socially beneficial activities. This claim can in turn be grounded in modern optimal tax theory.

The theory of optimal taxation is the leading scholarly approach to evaluating alternative tax regimes (Slemrod 1990, p. 157). In standard optimal tax theory, a tax system is designed to maximize a social welfare function. ${ }^{47}$ In the simplest models, all taxpayers are posited to be identical and the only policy question is what tax regime can most efficiently (that is, with the least distortion of taxpayer incentives) raise the desired level of revenue. In one early and important contribution to this literature, Frank Ramsey considered a government restricted to using commodity taxes, and found that the most efficient tax 
system features tax rates that are inversely proportional to the elasticity of demand for each commodity, such that the highest tax rates would apply to the commodities with the most inelastic demand. This is sometimes called the "Ramsey rule" (Ramsey 1927). ${ }^{48}$ Starting from the Ramsey rule and looking beyond commodity taxes, it was a short step to the conclusion that the optimal tax would be a lump-sum tax of some sort, a tax that has no effect on incentives, with the head tax being the simplest (and starkest) example. This conclusion, however, reveals the obvious limitation of the early Ramsey models: the failure to account for differences among taxpayers, especially differences in income or wealth and thus ability to pay taxes.

As reflected in actual effective tax rates, most modern developed societies, including the USA, have long been committed to a conception of distributional fairness (sometimes referred to as vertical equity) that includes a progressive distribution of the tax burden in which average tax rates rise with income. ${ }^{49}$ The head tax and virtually every other real world lump-sum tax fail miserably from the standpoint of imposing progressive tax burdens. In theory, if policymakers could observe differences in taxpayers' inherent abilities, they could design a tax that, if perfectly enforceable, would be both nondistortive and vertically equitable (Stiglitz 1987). However, such taxes are not practical, in part because of the impossibility of directly observing innate ability.

One alternative to adopting an ability tax, explored in the work of James Mirrlees, is to identify a tax base that is a rough proxy for ability and then to design a tax system that trades off society's distributional and efficiency goals (Mirrlees 1971, 1976, 1986). Under the Mirrlees model of the optimal income tax, taxpayers differ in their innate abilities to earn income, but such differences are unobservable by the taxing authority. What can be observed, however, are differences in individuals' incomes, which are assumed to be functions of both ability and effort. Taxing income, therefore, permits the government to impose progressive tax burdens that cannot be achieved with a head tax, but this comes at the cost of reducing efficiency because income taxation reduces the incentive to work. Mirrlees formalized what has become the well-known tradeoff in tax policy between efficiency and distributional fairness: the more progressive is the rate structure imposed on individual income, the greater the distortion of

48 In subsequent research, surveyed by Auerbach and Hines id., it developed that the inverse elasticity implication of the Ramsey rule is properly based on compensated elasticities of demand, those that abstract from the income effects of taxation and therefore depend exclusively on the effect of taxation on relative prices.

49 For data on tax burdens at different income levels in Organisation for Economic Cooperation and Development (OECD) countries over time, see OECD, Special feature: Trends in personal income tax and employee social security contribution schedules, available at: http://www.oecd.org/ctp/taxpolicy/50131824.pdf. 
individuals' work-leisure choices. And this distortion becomes increasingly pronounced as tax rates rise (Saez 2001).

Optimal tax theorists have also identified ways of trading off efficiency and distributional fairness in the context of commodity taxation. Whereas Ramsey originally assumed that all consumers are identical, Peter Diamond, building on the Ramsey framework, introduced consumers of different incomes and an inequality-averse social welfare function, finding that the resulting optimal commodity tax configuration requires consideration of both equality and efficiency considerations (id.). In Diamond's analysis, tax rates depend on two characteristics of a commodity: the extent to which it is disproportionately consumed by the rich and the extent to which its demand is price-insensitive, as both characteristics contribute to raising a commodity's optimal tax rate. In this model there is clearly a tradeoff between the distributional objective of a tax system, which dictates taxing goods consumed largely by the rich, and the efficiency objective, which dictates taxing goods with price-insensitive demands, since except in unusual circumstances the government cannot raise sufficient revenue by taxing only those goods that satisfy both criteria.

In addition to dealing with tradeoffs between distributional fairness and efficiency, optimal tax theory has attempted to incorporate the problem of externalities. In his classic analysis of optimal commodity taxation in an economy with externalities, Angar Sandmo identifies optimal Ramsey taxes in a setting in which consumption of certain goods imposes external harms or benefits on others in society (Sandmo 1975). The usual corrective policy for externalities is to subsidize beneficial activities and tax harmful activities (Pigou 1929). But such prescriptions will often be inconsistent with Ramsey's efficiency rationale for imposing taxes on price-insensitive commodities. Sandmo's innovation, therefore, was to show that the optimal commodity tax configuration in the presence of externalities entails taxes that have two components: a correction for externalities and a tax component that is inversely related to the price-sensitivity of demand. The externality consideration analyzed by Sandmo and the distributional consideration analyzed by Diamond can be combined in deriving optimal commodity tax rates, which is what Pirttila and Schob (1999) do. The Pirttila and Schob result, which is consistent with the findings of Sandmo and Diamond, is that optimal commodity tax rates are influenced by all three considerations: distributional fairness, externalities, and the price sensitivity of demand. One finding that follows from this analysis is that, just as there is usually a tradeoff between achieving distributional objectives and avoiding distorting work-leisure decisions, there is usually a tradeoff between achieving distributional objectives and correcting externalities. There is no such tradeoff when commodities that generate large negative externalities, and are therefore appropriately taxed heavily on externality grounds, also happen to be 
consumed disproportionately by the rich. A tax on negative-externality producing commodities consumed exclusively by the rich would, if such commodities existed, constitute the equivalent of the Holy Grail from an optimal tax perspective.

The AMT and AMxT fit comfortably into the optimal tax worldview, although they have not (as yet) been incorporated into optimal tax models. ${ }^{50}$ Under the original, highly simplified, frameworks of Ramsey and Mirrlees in which consumers have common preferences, there is no need for an AMT or an AMxT. ${ }^{51}$ All taxes, whether on commodities or income, are imposed uniformly, with no special subsidies for particular types of expenditures and hence no worries about the tradeoffs that such subsidies entail. However, once distributional and externality concerns are introduced into a setting with individual heterogeneity, the optimal tax case for an AMT/AMxT becomes evident.

To see this point, consider again the example of the charitable contribution deduction discussed in connection with Tables 1 through 4 above. Under the tax-preference view of charitable contributions, when taxpayers give to charities that perform functions otherwise performed by government actors, a positive externality is produced; a public good is provided without the need for distortionary taxation. On this view, overall social welfare can be enhanced if such a positive externality were subsidized. How might this be done? If the government can observe charitable contributions as well as pretax incomes, income tax payments can be conditioned on both. Therefore, an optimal income tax system theoretically includes deductions or credits for individual charitable contributions, with the goal again of encouraging greater contributions. But if this is the justification for the charitable contribution deduction, ${ }^{52}$ the now-familiar

50 Saez (2004) analyzes an optimal tax model with subsidies for charitable contributions, but explains that due to the complexity of the problem his model is restricted to considering individuals with identical preferences and a government that must use a linear tax system with an exempt amount and a single income tax rate. Diamond (2006) considers optimal tax subsidies for charitable contributions in settings in which individuals have potentially differing preferences and income levels, and the government has available a more general income tax system with marginal tax rates that can vary with income. The Diamond study does not consider the potential role of an AMT/AMxT combination, but does note that the optimal pattern of tax subsidies for charitable contributions generally varies across income and contribution levels. The precise nature of the resulting optimal tax and subsidy combination depends on so many aspects of individual preferences, the skill distribution, and the social welfare function that it is not possible for the study to characterize its features, though it is clear that there are circumstances in which provision of greater tax benefits for charitable contributions by high-income taxpayers permits the government to impose higher top tax rates.

51 Most of the optimal tax literature continues to rely on the assumption that consumers have identical preferences, reflecting not only the complexity of the alternatives but also the need to incorporate value judgments about redistributions between consumers with differing preferences. Exceptions include Sandmo (1993); Boadway et al. (2002); Saez (2002); and Kaplow (2008). 
optimal-tax tradeoff emerges: the generosity afforded charitable contributions is potentially limited by the government's other objective of producing an acceptable after-tax distribution of income. A critical consideration in the design of an optimal tax in this setting is whether the government, in evaluating the distribution of income, considers an individual "rich" or "poor" if the individual has a very high income but so many charitable contributions that little is left over for personal consumption. Taking such a person to be "rich" for normative purposes (since a high income level affords extensive options and command over resources, and individuals presumably benefit from their own charitable contributions), the inequality-averse social welfare function implies that tax benefits directed at high-income charitable contributors are strong candidates for reductions in the name of redistribution. ${ }^{53}$ This insight is not that optimal tax theory calls for high-income individuals to be denied charitable deductions; rather it suggests only that, because of the tradeoff between encouraging beneficial externalities and achieving distributional equity, there should be a point at which charitable deductions should be limited, as the distributional goal takes precedence over the externalities goal.

The combination of an AMT and AMxT would serve just this function. That is, if the charitable contribution deduction were viewed as a subsidy for externality producing consumption expenditures, then treating the charitable contribution as a tax preference for both AMT and AMxT purposes would have the effect of limiting the tradeoff of progressivity in the service of encouraging donations. The AMT would limit the loss of distributional equity between high income taxpayers who have a preference for giving to charity and low income taxpayers (maintaining distributional equity, for example, between Taxpayers A and B in Table 4 above); and the AMxT would limit the loss of distributional equity between taxpayers with equal economic income but with strongly different preferences for charitable giving (maintaining distributional equity, for example, between Taxpayers A and C in Table 4). ${ }^{54}$ Furthermore, the existence of an AMT and AMxT permits policymakers to achieve a greater degree of progressivity (to impose higher effective tax burdens on the Taxpayer A's of the world and lower effective rates on the Taxpayer B's of

53 To treat such charitably inclined donors as "rich" is equivalent to treating their charitable contributions as consumption choices.

54 Some tax theorists, such as Musgrave $(1959,1990)$ would describe the goal of maintaining distributional equity between Taxpayers A and B an example of "vertical equity" (taxing unequals unequally) and the goal of maintaining distributional equity between Taxpayers A and C an example of "horizontal equity" (taxing equals equally). Others, such as Kaplow (1989), regard horizontal equity as having no independent theoretical content apart from vertical equity. 
the world) without having to worry that the inequities described above will become too egregious. This flexibility with the progressive structure of regular income tax rates reflects one of the insurance functions of the AMT and AMxT. Put differently, with an AMT and AMxT it is possible to have more progressive regular income tax rates than would otherwise be feasible or desirable.

It is important to emphasize that the imposition of an AMT and AMxT does not contradict the rationale that serves to justify any given tax preference. Rather, the AMT/AMxT combination represents a way of coordinating contradictory commitments: the commitment to the tax preference in question, as well as the commitment to progressivity and tax fairness generally.

The deduction for state and local income and property taxes is another example, and is by far the largest preference item under the existing AMT. ${ }^{55}$ There is considerable controversy over the desirability of permitting individual taxpayers to claim state and local tax deductions, despite their longstanding availability. A standard justification for state and local tax deductibility is that taxpayers do not have access to resources that are taxed by state and local governments, so a fair accounting of disposable annual income would permit the deduction (e.g., Bittker 1973). ${ }^{56}$ On this view, the deduction should not be considered a tax preference under an AMT or AMxT. However, this deduction might instead be understood as a subsidy designed to have the tax system as a whole avoid discouraging state and local spending, a portion of the benefits of which-those that come in the form of higher taxable incomes-are captured by the rest of the country in higher income taxes (Kaplow 1996; Hatfield 2013). ${ }^{57}$ If there is a sound subsidy rationale for permitting taxpayers to deduct state and local income tax payments, one might question why an AMT or AMxT denies the deduction for those facing very low or very high tax rates. Denying the deduction has the effect of removing the implied federal tax subsidy for incurring state and local tax liabilities. However, as argued

55 The Joint Committee on Taxation estimates that, in 2006, individual taxpayers subject to the AMT had $\$ 90.9$ billion in state and local tax payments that were deductible in calculating their regular income taxes but nondeductible in calculating their AMTs. All other AMT preferences and adjustments, including personal exemptions, miscellaneous itemized expense deductions, and all others, added to $\$ 55.1$ billion. U.S. Congress Joint Committee on Taxation (2007).

56 This argument was particularly potent in the era in which the top federal marginal income tax rate exceeded 90 percent, and some states imposed significant personal income tax rates in addition. Critics argue that that availability of the federal income tax deduction indirectly encourages state and local governments to impose taxes the burden of which is effectively shared by the U.S. Treasury, thereby providing an inefficient subsidy for state and local government expenditures. See, for example, Gramlich (1985).

57 Many though not all of the expenditures of state and local governments are intended to encourage economic activity and income production, the product of which is then taxed by the federal government. 
above, the reason to have a system that generally provides a deduction but then selectively removes it must depend either on a desire to impose obligations on certain taxpayers or on an unwillingness to encourage the subsidized activity on their part.

\section{A MAXIMUM TAX TO ACCOMPANY A MINIMUM TAX}

The current U.S. tax system has an AMT without an AMxT, though it is noteworthy that the top regular income tax rate is 39.6 percent, quite a bit below the top AMxT rate contemplated by Senator Long and the top regular income tax rate in the 1969 U.S. Treasury proposal. In that rather restricted sense the USA has adopted an AMxT, since tax burdens are limited to 39.6 percent of the current definition of taxable income. There is another sense as well. Parts of the existing federal income tax regime already have some of the important properties of an AMxT-namely, that they constrain divergence of effective tax rates between individuals of equal economic incomes and they maintain divergence of effective tax rates between individuals of different economic incomes. Two of the noteworthy AMxT-like provisions in the current Code are deduction/exclusion phase outs and the standard-deduction/itemized-deduction option.

An income tax without an AMxT but with a system of phasing out tax deductions for taxpayers above specified income levels can be made equivalent to an income tax with an AMxT. Consider, for example, a taxpayer with an income of $\$ 1,600,000$, no tax deductions, and a marginal tax rate of 40 percent; suppose further that 40 percent is the highest income tax bracket. That taxpayer clearly faces a maximum tax rate of 40 percent. If certain activities and expenditures are rewarded by the tax system with deductions, but the deductions phase out for taxpayers with incomes between $\$ 200,000-\$ 500,000$, then the hypothetical taxpayer with $\$ 1.6$ million in income would receive no benefit from any activities or expenditures that, for taxpayers at lower income levels, do generate tax benefits. The imposition of a maximum tax rate and removal of tax benefits for specified activities and expenditures is characteristic of a maximum tax.

The standard deduction is another component of the current income tax that exhibits some of the properties of an AMxT for a very different part of the income distribution. ${ }^{58}$ Taxpayers are entitled either to itemize their deductions or to claim the standard deduction amount, which in 2014 is $\$ 6,200$ for an unmarried taxpayer and $\$ 12,400$ for a married couple. Since the standard deduction is optional, it is possible to think of potential tax liability using the

58 For other perspectives on the justification for the standard deduction, see McCaffery (1990); Samansky (1991); Slemrod \& Yitzhaki (1994); Kaplow (1994); and Brooks (2011). 
standard deduction as an alternative maximum tax for taxpayers who would otherwise only be entitled to claim whatever deductions they can itemize. ${ }^{59}$ Thus, the standard deduction has the properties of an AMxT: It constrains the divergence between the average tax rate paid by individuals with many itemized deductions and the average tax rate paid by individuals of equal economic income with relatively few itemized deductions; put differently, the standard deduction constrains the progressivity divergence between the tax preference preferers and the nonpreferers, which, as this article notes, is the primary function of an AMxT, and of an AMT for that matter. Furthermore, the roughly two-thirds of the taxpaying population that takes the standard deduction ${ }^{60}$ loses the benefits of preference items for which an itemized deduction is otherwise available, presumably then also losing whatever incentive the tax deduction would have provided to undertake the preferred activities.

The persistence and apparent popularity of the standard deduction and the phase outs of various personal deductions suggest that the taxpaying public and its representatives in Congress are comfortable with at least a step in the direction of an AMxT-type structure in the income tax. Despite the AMxT-like elements within the current U.S. tax system, however, the current system does not include a coherently designed AMT and AMxT. Tax deductions that phase out at higher income levels do not correspond to the tax deductions that are denied in defining income for AMT purposes. I.R.C. $\$ 68$ reduces certain personal itemized deductions by 3 percent of the amount that adjusted gross income exceeds $\$ 305,050$, to a maximum reduction of 80 percent. This socalled 3 percent haircut applies to all personal deductions other than those for medical expenses, investment interest, and casualty, theft, and gambling losses. Since personal deductions include those for charitable contributions and other activities and expenditures not implicated in calculating income for AMT purposes, and do not include many of the adjustments that are used in calculating income for AMT purposes, the I.R.C. $\$ 68$ phase-out conforms only very loosely, if at all, to what an AMxT would do. Which is not to say that the list of deductions that are phased out should be changed to match the list of deductions currently excluded under the existing AMT. That is, the particular list of tax preferences currently disallowed under the existing AMT is not necessarily the list that would be adopted by a policymaker pursuing a

59 The tax limiting feature of the standard deduction was perhaps even more evident in the first decades following its introduction in 1944. From 1944-1969 the standard deduction was equal to 10 percent of adjusted gross income, up to a maximum of \$1,000; and from 1964-1969 the minimum standard deduction was \$200.

60 Justin Bryan reports that 65.6 percent of U.S. individual income tax filers claimed the standard deduction in 2010 (Bryan 2012, p. 8). 
coherent vision of the AMT/AMxT along the lines suggested in this Article. For example, whether it makes sense that personal exemption deductions are currently treated as tax preferences (rather than as adjustments reflecting a household's ability to pay taxes) while charitable contributions are not currently treated as tax preferences is at least debatable. Nor is it that the change should be in the opposite direction-that the list of AMT tax preferences should be altered to reflect the deductions that are currently phased out under various provisions in the code, including I.R.C. \$68. Rather the point is that, whatever the definitive list of tax preferences turns out to be, those provisions should be part of a comprehensive and consistent solution to the problem of divergence from progressivity. ${ }^{61}$

The underlying rationale of the AMT and AMxT suggests some guidelines in choosing activities to be treated as tax preferences in calculating obligations under the AMT and AMxT. Activities such as charitable contributions or R\&D spending, that Congress seeks to encourage based on their social spillovers, should be treated as tax preferences to the extent that the incidence of the associated tax benefits actually falls on taxpayers engaging in the activities. By comparison, adjustments to measured income, such as miscellaneous itemized deductions, make very poor candidates for tax preference treatment, since there is neither an efficiency basis nor an equity basis for preventing taxpayers from claiming these deductions.

A similar critique could be made of the standard deduction, which approximates only very roughly one aspect of an AMxT. The standard deduction operates as an AMxT only because it is offered as an alternative to the package of itemized deductions; one can take either the standard deduction or the sum of itemized deductions. Obviously the list of itemized deductions is not the same as the list of tax preferences under the current AMT, so the identification, and consistent use, of appropriate tax preferences both for the AMT and as alternatives to the standard deduction would be an important step in strengthening the AMxT features of the current income tax. Another difference between the effect of the standard deduction and that of an AMxT is that the standard deduction is not tied to economic income. Very high income individuals with no itemized deductions currently enjoy the same standard deduction as very low income individuals, whereas an AMxT-like system would vary the standard deduction amount with income (as U.S. law did from 1944-1969).

The preceding analysis suggests that a more comprehensive and consistent AMT/AMxT strategy would include: repeal of the standard deduction, along

61 One should not minimize the difficulty of this task, which is evidenced by the gallons of ink spilled in scholarly debates over whether there is such a thing as a "comprehensive tax base" and whether the phrase "tax expenditure" can be meaningfully defined. 
with income-triggered phase outs of deductions, exclusions, and credits to supplement the existing AMT regime; and the adoption of a new, comprehensive set of alternative minimum and alternative maximum tax rates, which would apply to the alternative tax base, defined as the regular income tax base less any preferences. Under such an approach, it would be best to have a schedule of AMT and AMxT rates for several different levels of economic income.

To illustrate the operation of multiple AMT and AMxT brackets, return to the hypothetical from above, only this time add Taxpayer $\mathrm{D}$, a retiree who has $\$ 30,000$ of taxable income, of which he somehow spends $\$ 25,000$ on charitable contributions. Even at this lower level of income, policymakers may wish to constrain the divergence between the effective tax rate paid by $\mathrm{D}$, the lowincome preference preferer, and the rate paid by $\mathrm{B}$, the low-income preference nonpreferer. Thus, the AMT, instead of having a $\$ 30,000$ exclusion, could have a different set of alternative minimum and maximum rates for lower levels of income. ${ }^{62}$ In the original hypothetical, regular income tax rates were $15 \%$ (up to $\$ 40,000$ ); $35 \%$ ( $\$ 40,000$ to $\$ 150,000$ ), and $50 \%$ (over $\$ 150,000$ ), with a single AMT rate of $25 \%$ and a single AMxT rate of $35 \%$, with an exclusion of $\$ 30,000$. There could instead be a menu of AMT and AMxT rates at different levels of (alternative) income. For example, imagine AMT and AMxT rates of $5 \%$ and $12 \%$, respectively, for income up to $\$ 40,000$; of $10 \%$ and $30 \%$ for income between $\$ 40,000$ and $\$ 150,000$; and of $25 \%$ and $35 \%$ for income over $\$ 150,000$. This system produces tax obligations that are depicted in Table 5.

Recall that under an AMT/AMxT regime, the taxpayer pays the higher of his AMT and regular tax liabilities and the lower of his regular tax and AMxT liabilities. Thus, in this example Taxpayers A and D pay their AMT amounts; and Taxpayers B and C pay their AMxT amounts. As a result, Taxpayer B pays an average rate of 12 percent on economic income; whereas taxpayer D pays an average rate of 5 percent. In the absence of an AMT and AMxT, B's tax obligation would be 15 percent of income, and D's would be 2.5 percent of income. Thus the AMT and AMxT together reduce average tax rate disparities among these low-income taxpayers just as they do among high-income A and C.

The complexity of such an approach is apparent, though if adoption of a multi-bracket AMT/AMxT combination were accompanied by removing the phase-outs and other limitations on preference items embedded in the current tax law, the net effect might very well be to reduce the total complexity and improve the net transparency of the tax system, in part because marginal tax rates under the AMT and AMxT are considerably more transparent than those

62 Again, the examples here ignore personal exemption deductions. 
Table 5. Effective Tax Rates with Multiple AMT and AMxT Brackets: Reducing Disparities between High-Income and Low-Income Preference Preferers and NonPreferers

\begin{tabular}{llllll}
\hline Taxpayer & Income & $\begin{array}{l}\text { Charitable } \\
\text { contribution }\end{array}$ & $\begin{array}{l}\text { Regular tax / } \\
\text { (effective rate) }\end{array}$ & $\begin{array}{l}\text { AMT / } \\
\text { (effective rate) }\end{array}$ & $\begin{array}{l}\text { AMxT / } \\
\text { (effective rate) }\end{array}$ \\
\hline A & $\$ 300,000$ & $\$ 200,000$ & $\$ 27,000 /(9 \%)$ & $\mathbf{\$ 5 0 , 5 0 0 / ( 1 6 . 8 \% )}$ & $\$ 90,300 /(30.1 \%)$ \\
B & $\$ 30,000$ & $\$ 0$ & $\$ 4500 /(15 \%)$ & $\$ 1500 /(5 \%)$ & $\$ 3600 /(12 \%)$ \\
C & $\$ 300,000$ & $\$ 0$ & $\$ 119,500 /(39.8 \%)$ & $\$ 50,500 /(16.8 \%)$ & $\$ \mathbf{9 0 , 3 0 0 / ( 3 0 . 1 \% )}$ \\
D & $\$ 30,000$ & $\$ 25,000$ & $\$ 750 /(2.5 \%)$ & $\$ \mathbf{\$ 1 5 0 0 / ( 5 \% )}$ & $\$ 3600 /(12 \%)$ \\
\hline
\end{tabular}

under the regular income tax subject to varying phaseouts. ${ }^{63}$ But with computer software doing the actual calculations, the result, at least from an ex post perspective, may well be an overall improvement in progressivity of the Internal Revenue Code. From an ex ante planning perspective, however, the challenge a comprehensive AMT/AMxT regime would present some taxpayers could be daunting, much as is the income tax currently.

The AMT and AMxT are designed to address issues related to taxpayer heterogeneity, and from a practical standpoint it is worth making these adjustments, and dealing with the complexity for which they are responsible, only if taxpayers of similar incomes differ to sufficient degree in their tax preference use. Without knowing rates and bases it is impossible to say how many taxpayers would be subject to a hypothetical AMxT, though to the extent that Congress currently feels constrained in setting tax rates by the potential inequity of subjecting taxpayers without many tax preference items to high rates of tax, then the issue would appear to be of sufficient importance to warrant a more direct treatment than the current method of offering the standard deduction to provide AMxT-like treatment to lower income taxpayers.

Although introduction of an AMxT would increase the complexity of the Internal Revenue Code, it would also afford Congress the opportunity to pursue tax policy objectives that might be difficult to achieve in other ways. For example, a Congress that is hungry for additional tax revenue and not inclined to increase burdens on lower-income individuals might increase the top regular income tax rate from 39.6 percent to 45 percent, while simultaneously introducing an AMxT with a tax base defined in the same way as the AMT, and with a

63 Incomes that fluctuate significantly between years provide a source of complexity not explicitly analyzed in this article but that would need to be addressed in structuring an AMxT. Under current law taxpayers subject to the AMT in year one but whose situations change sufficiently in year two that they are subject only to the regular income tax are entitled to claim credits for year one AMT payments against year two regular tax liabilities. An analogous AMxT treatment is that taxpayers subject to the AMxT in year one but the regular income tax in year two would face additional year two tax liability for a portion of the year one tax saving from the AMxT. 
rate of roughly 37 percent. Such a change could be tailored to increase government revenue, thereby appealing to liberals as a tax increase on the rich, while mollifying conservatives by limiting tax burdens with an AMxT at a rate lower than the previous top personal rate. In the strange world that is politics of course anything can happen, and the same reasoning might convince both political sides that they would lose from such a reform; but one of the appeals of an AMxT is that Congress thereby has greater freedom with top personal rates in a progressive tax structure.

Where does this analysis leave a government contemplating an AMT and an AMxT? This article suggests that having both an AMT and an AMxT maintains the divergence of effective tax rates across income classes and constrains the divergence of average tax rates within income classes. The important point to emphasize is that this argument applies with equal force both to an AMT and to an AMxT. In addition to their direct effects, the AMT and AMxT afford the government the opportunity to offer more tax preferences than would otherwise be prudent given the resulting disparities in tax burdens. An AMT alone offers the government some insurance against outcomes in which tax preference preferers are taxed too lightly, but this insurance guards only partially against the possibility that high-income tax preference preferers might significantly reduce their tax liabilities. The government could offer greater tax preferences and simultaneously increase top tax rates, but in the absence of an AMxT doing so risks overtaxing some high income individuals who have few preference items. From the standpoint of maintaining a progressive income tax with preferences, the current U.S. federal income tax, with its AMT and no AMxT, goes only so far. Adoption of an AMxT, together with adjustments to the AMT, would complete the job that the AMT started.

How an AMxT, or for that matter an AMT, fits into a scheme of optimal taxation depends rather acutely on features of the income distribution, individual preferences, and social equality norms that are not settled. As a practical matter, however, which is the sphere that the AMT has inhabited since its introduction, there is a reasonable case for insisting that Congress either enact an AMxT to accompany the AMT, or else-if tax progressivity together with the provision of tax preferences does not advance the nation's tax policy goals-abandon the AMT altogether.

\section{REFERENCES}

Aitsebaomo, Gabriel O. 2005. The Individual Alternative Minimum Tax: An Argument in Favor of Repeal. University of Missouri Kansas City L. Rev. 74, 335-363. 
American Taxpayer Relief Act of 2012. Pub. L. No. 112-240, \$ 104, 126 Stat 2313, 2320-23 (2013).

Auerbach, Alan J., \& James R. Hines Jr. 2002. Taxation and Economic Efficiency. In Alan J. Auerbach, \& Martin Feldstein (eds.), Handbook of Public Economics, vol. 3. Amsterdam: North-Holland, pp. 1347-1421.

Baneman, Daniel, Jim Nunns, Jeff Rohaly, Eric Toder, \& Roberton Williams.

2011. Options to Limit the Benefit of Tax Expenditures for High-Income Households. Washington DC: Tax Policy Center.

Beale, Linda M. 2004. Congress Fiddles While Middle America Burns: Amending the AMT (and Regular Tax). Florida Tax Rev. 6, 811-947.

Bittker, Boris I. 1965-1966. An Optional Simplified Income Tax? Tax L. Rev. 21, $1-51$.

1972. Charitable Contributions: Tax Deductions or Matching Grants? Tax L. Rev. 28, 37-63.

- 1973. Income Tax Deductions, Credits, and Subsidies for Personal Expenditures. J. L. \& Econ. 16, 193-213.

Boadway, Robin, Maurice Marchand, Pierre Pestieau, \& Maria del Mar Racionero. 2002. Optimal Redistribution with Heterogeneous Preferences for Leisure. J. Public Econ. Theory 4, 475-498.

Bradford, David. 1986. Untangling the Income Tax. Cambridge MA: Harvard University Press.

Branham, Elizabeth. 2008-09. Closing the Tax Gap: Encouraging Voluntary Compliance Through Mass-Media Publication of High-Profile Tax Issues. Hastings L. J. 60, 1507-1533.

Brooks, II, John, R. 2011. Doing too much: The Standard Deduction and the Conflict between Progressivity and Simplification. Columbia J. Tax L. 2, 203-246.

Bryan, Justin. 2012. Individual Income Tax Returns, 2010. Statistics of Income Bulletin 32, 5-78.

Burman, Leonard E., William G. Gale, Jeffrey Rohaly, \& Benjamin H. Harris. 2002. The Individual AMT: Problems and Potential Solutions. National Tax J. 55, 555-596.

Burman, Leonard E., William G. Gale, \& Jeffrey Rohaly. 2003a. The AMT: Projections and Problems. Tax Notes 100, 105-117.

- 2003b. Policy Watch: The Expanding Reach of the Individual Alternative Minimum Tax. J. Econ. Perspectives 17, 173-186.

Burman, Leonard E., William G. Gale, Greg Leiserson, \& Jeffrey Rohaly. 2007. The AMT: What's Wrong and How to Fix It. National Tax J. 60, 385-405.

Burman, Leonard E., \& Greg Leiserson. 2007. A Simple, Progressive Replacement for the AMT. Tax Notes 119, 945-955. 
Congressional Budget Office. 2010. Economic and Budget Issue Brief: The Individual Alternative Minimum Tax. Available at: http://www.cbo.gov/ sites/default/files/cbofiles/ftpdocs/108xx/doc10800/01-15-amt_brief.pdf.

Diamond, Peter A. 2006. Optimal Tax Treatment of Private Contributions for Public Goods with and without Warm Glow Preferences. J. Public Econ. 90, 897-919.

Elkins, David. 2006. Horizontal Equity as a Principle of Tax Theory. Yale L. \& Policy Rev. 24, 43-90.

Feenberg, Daniel, \& James M. Poterba. 2004. The Alternative Minimum Tax and Effective Marginal Tax Rates. National Tax J. 57, 407-427.

Fullerton, Don, \& Gilbert E. Metcalf. 2002. Tax Incidence. In Alan J. Auerbach, \& Martin Feldstein (eds.), Handbook of Public Economics, vol. 4. Amsterdam: North-Holland, pp. 1787-1872.

Galle, Brian, \& Jonathan Klick. 2010. Recessions and the Social Safety Net: The Alternative Minimum Tax as a Counter-Cyclical Fiscal Stabilizer. Stanford L. Rev. 63, 187-246.

Gensler, Howard. 1985. A Simplified Internal Revenue Code. Taxes 63, 279-303.

Gleckman, Howard. 2012. The Turbo Tax Paradox. Tax Vox, The Tax Policy Center Blog. Available at http://taxvox.taxpolicycenter.org/2012/04/17/theturbo-tax-paradox/.

Graetz, Michael J., \& Emil M. Sunley. 1988. Minimum Taxes and Comprehensive Tax Reform. In Henry J. Aaron, Harvey Galper, \& Joseph A. Pechman (eds.), Uneasy Compromise: Problems of a Hybrid Income-Consumption Tax. Washington DC: Brookings, pp. 385-419.

Gramlich, Edward M. 1985. The Deductibility of State and Local Taxes. National Tax J. 38, 447-465.

Griffin, R. Jason. 2004. The Individual Alternative Minimum Tax: Is It Touching People That It Shouldn't Be? Houston Bus. \& Tax L. J. 4, 259-291. Harvey, Robert P., \& Jerry Tempalski. 1997. The Individual AMT: Why It Matters. National Tax J. 50, 453-474.

Hatfield, John William. 2013. Revenue Decentralization, the Local Income Tax Deduction, and the Provision of Public Goods. National Tax J. 66, 97-115. Hennig, Cherie, Wendy Gelman, \& John O. Everett. 2008. Taxpayers Take the AMT to Court: A Burden That Needs Fixin'. Taxes 86, 37-46.

Kaplow, Louis. 1989. Horizontal Equity: Measures in Search of a Principle. National Tax J. 42, 139-150.

- 1994. The Standard Deduction and Floors in the Income Tax. Tax L. Rev. 50, 1-32.

- 1996. Fiscal Federalism and the Deductibility of State and Local Taxes under the Federal Income Tax. Virginia L. R. 82, 413-492. 
2008. Optimal policy with Heterogeneous Preferences. B.E. J. Econ. Analysis \& Policy (Advances) 8, 1-28.

Karlinsky, Stewart S. 1995. A Report on Reforming the Alternative Minimum Tax System. Am. J. Tax Policy 12, 139-154.

Lerman, Allen H., \& Peter S. Lee. 2005. Evaluating the Ability of the Individual Taxpayer Burden Model to Measure Components of Taxpayer Burden: The Alternative Minimum Tax as a Case Study. In IRS Research Bulletin: Recent IRS Research on Tax Administration and Compliance. Washington DC: Internal Revenue Service, pp. 139-172.

Lindsey, Vada Waters. 2001. The Widening Gap under the Internal Revenue Code: The Need for Renewed Progressivity. Florida Tax Rev. 5, 1-47.

Listokin, Yair. 2011. A Note on Tax Expenditures and Business Cycle Fluctuations. Proceedings of the 2009 National Tax Association Annual Conference. pp. 195-202.

Mankiw, N. Gregory, Matthew C. Weinzierl, \& Danny Yagan. 2009. Optimal Taxation in Theory and Practice. J. Econ. Perspectives 23, 147-174.

McCaffery, Edward J. 1990. The Holy Grail of Tax Simplification. Wisconsin L. Rev. 1990, 1267-1322.

Mirrlees, James A. 1971. An Exploration in the Theory of Optimum Income Taxation. Rev. Econ. Studies 38, 175-208. . 1976. Optimal Tax Theory: A Synthesis. J. Public Econ 6, 327-358. . 1986. The Theory of Optimal Taxation. In Kenneth J. Arrow, \& Michael D. Intrilligator (eds.), Handbook of Mathematical Economics, vol. 3. Amsterdam: North-Holland, pp. 1197-1249.

Musgrave, Richard A. 1959. The Theory of Public Finance. New York: McGrawHill.

1990. Horizontal Equity, Once More. National Tax J. 43, 113-122.

Musgrave, Richard A., \& Tun Thin. 1948. Income Tax Progression, 1929-48. J. Political Econ. 56, 498-514.

National Taxpayer Advocate. 2012. 2012 Annual Report to Congress, vol. 1. Washington DC: Internal Revenue Service.

O'Shaughnessy, Brian L. 2006. The Growing Need for an Alternative to the AMT. Kansas J. L. \& Public Policy 16, 67-83.

Peroni, Robert J. 2003. A Hitchhiker's Guide to Reform of the Foreign Tax Credit Limitation. Southern Methodist U. L. Rev. 56, 391-399.

Pigou, A.C. 1929. The Economics of Welfare, 3rd Edition. London: Macmillan. Pirttila, Jukka, \& Ronnie Schob. 1999. Redistribution and Internalization: The Many-Person Ramsey Rule Revisited. Public Finance Rev. 27, 541-560.

Poterba, James M. 1986. Explaining the Yield Spread between Taxable and Taxexempt Bonds: The Role of Expected Tax Policy. In Harvey S. Rosen (ed.), 
Studies in State and Local Public Finance. Chicago: University of Chicago Press, pp. 5-52.

President's Advisory Panel on Federal Tax Reform. 2005. Simple. Fair, and ProGrowth: Proposals to Fix America's Tax System. Washington, DC: U.S. Government Printing Office.

Ramsey, Frank P. 1927. A Contribution to the Theory of Taxation. Econ. J. 37, 47-61.

Rosen, Harvey S. 1980. What Is Labor Supply and Do Taxes Affect It? Am. Econ. Rev. 70, 171-176.

Saez, Emmanuel. 2001. Using Elasticities to Derive Optimal Income Tax Rates. Rev. Econ. Stud. 68, 205-229.

- 2002. The Desirability of Commodity Taxation under Non-Linear Income Taxation and Heterogeneous Tastes. J. Public Econ. 83, 217-230.

- 2004. The Optimal Treatment of Tax Expenditures. J. Public Econ. 88, 2657-2684.

Saez, Emmanuel, Joel Slemrod, \& Seth H. Giertz. 2012. The Elasticity of Taxable

Income with Respect to Marginal Tax Rates: A Critical Review. J. Econ. Literature 50, 3-50.

Sager, Laura, \& Stephen Cohen. 2000. How the Income Tax Undermines Civil Rights Law. Southern California L. Rev. 73, 1075-1104.

Samansky, Allan J. 1991. Nonstandard Thoughts about the Standard Deduction. Utah L. Rev. 1991, 531-556.

Sandmo, Agnar. 1975. Optimal Taxation in the Presence of Externalities. Swedish J. Econ. 77, 86-98.

- 1993. Optimal Redistribution When Tastes Differ. FinanzArchiv 50, 149-163.

Shaviro, Daniel. 1988. Perception, Reality and Strategy: The New Alternative Minimum Tax. Taxes 66, 91-102.

-2001. Tax Simplification and the Alternative Minimum Tax. Tax Notes 91, 1455-1468.

Slemrod, Joel. 1990. Optimal Taxation and Optimal Tax Systems. J. Econ. Perspectives 4, 157-178.

Slemrod, Joel, \& Shlomo Yitzhaki. 1994. Analyzing the Standard Deduction as a Presumptive Tax. Intl Tax \& Pub. Finan. 1, 25-34.

Stiglitz, Joseph E. 1987. Pareto Efficient and Optimal Taxation and the New New Welfare Economics. In Alan J. Auerbach, \& Martin Feldstein (eds.), Handbook of Public Economics, vol. 2. Amsterdam: North-Holland, pp. 991-1042.

Surrey, Stanley S. 1970. Tax Incentives as a Device for Implementing Government Policy: A Comparison with Direct Government Expenditures. Harvard L. Rev. 83, 705-738. 
Traeger, Charles H. 1967. Simplified Taxable Income. Stanford L. Rev. 19, 593-607.

U.S. Congress Conference Committee. 1968. Revenue and Expenditure Control Act of 1968, Explanation of the Bill H.R. 15414 As Agreed to in Conference. Washington, DC: U.S. Government Printing Office.

U.S. Congress Joint Committee on Taxation. 1970. General Explanation of the Tax Reform Act of 1969. Washington DC, U.S. Government Printing Office.. . 1983. General Explanation of the Revenue Provisions of the Tax Equity and Fiscal Responsibility Act of 1982. Washington DC: U.S. Government Printing Office.

. 2004. Description of Revenue Provisions Contained in the President's Fiscal Year 2005 Budget Proposal. Washington DC: Joint Committee on Taxation.

2007. Present Law and Background Relating to the Individual Alternative Minimum Tax. Washington DC: Joint Committee on Taxation.

U.S. Congress Joint Economic Committee. 2001. The Alternative Minimum Tax for Individuals: A Growing Burden. Washington DC: Joint Economic Committee.

U.S. Government Accountability Office. 2005. Tax Expenditures Represent a Substantial Federal Commitment and Need to Be Reexamined. Washington DC: U.S. Government Accountability Office.

U.S. Treasury Department. 1969. Tax Reform Studies and Proposals. Washington DC: U.S. Government Printing Office. 